\title{
Co-ingestion of cluster dextrin carbohydrate does not increase exogenous protein-derived amino acid release or myofibrillar protein synthesis following a whole-body resistance exercise in moderately trained younger males: a double-blinded randomized controlled crossover trial
}

\author{
Yusuke Nishimura ${ }^{1,2} \oplus \cdot$ Mikkel Jensen $^{3} \cdot$ Jacob Bülow $^{3} \cdot$ Thomas Tagmose Thomsen $^{3} \cdot$ Takuma Arimitsu $^{2}$. \\ Gerrit van Hall ${ }^{4,5} \cdot$ Satoshi Fujita ${ }^{2} \cdot$ Lars Holm $^{1,3,5}$
}

Received: 5 August 2021 / Accepted: 9 December 2021 / Published online: 19 February 2022

(c) The Author(s) 2022

\begin{abstract}
Purpose This study investigates if co-ingestion of cluster dextrin (CDX) augments the appearance of intrinsically labeled meat protein hydrolysate-derived amino acid ( $\mathrm{D}_{5}$-phenylalanine), Akt/mTORC1 signaling, and myofibrillar protein fractional synthetic rate (FSR).

Methods Ten moderately trained healthy males (age: $21.5 \pm 2.1$ years, body mass: $75.7 \pm 7.6 \mathrm{~kg}$, body mass index (BMI): $22.9 \pm 2.1 \mathrm{~kg} / \mathrm{m}^{2}$ ) were included for a double-blinded randomized controlled crossover trial. Either $75 \mathrm{~g}$ of CDX or glucose (GLC) was given in conjunction with meat protein hydrolysate $\left(0.6 \mathrm{~g}\right.$ protein $\left.* \mathrm{FFM}^{-1}\right)$ following a whole-body resistance exercise. A primed-continuous intravenous infusion of L- $\left[{ }^{15} \mathrm{~N}\right]$-phenylalanine with serial muscle biopsies and venous blood sampling was performed.

Results A time $\times$ group interaction effect was found for serum $\mathrm{D}_{5}$-phenylalanine enrichment $(P<0.01)$. Serum EAA and BCAA concentrations showed a main effect for group $(P<0.05) . \mathrm{T}_{\max }$ serum BCAA was greater in CDX as compared to GLC $(P<0.05)$. However, iAUC of all serum parameters did not differ between CDX and GLC $(P>0.05)$. $\mathrm{T}_{\max }$ serum EAA showed a trend towards a statistical significance favoring CDX over GLC. The phosphorylation of p70S6K ${ }^{\text {Thr3 } 389}, \mathrm{rpS6}^{\text {Ser240/244, }}$ ERK1/2 ${ }^{\text {Thr202/Tyr204 }}$ was greater in CDX compared to GLC $(P<0.05)$. However, postprandial myofibrillar FSR did not differ between $\mathrm{CDX}$ and $\operatorname{GLC}(P=0.17)$.

Conclusion In moderately trained younger males, co-ingestion of CDX with meat protein hydrolysate does not augment the postprandial amino acid availability or myofibrillar FSR as compared to co-ingestion of GLC during the recovery from a whole-body resistance exercise despite an increased intramuscular signaling.
\end{abstract}

Trial registration ClinicalTrials.gov ID: NCT03303729 (registered on October 3, 2017).

Keywords Resistance exercise $\cdot$ Muscle protein synthesis $\cdot$ Stable isotope tracer $\cdot$ Amino acids $\cdot$ Intrinsically labeled protein $\cdot$ mTORC1

Lars Holm

L.Holm@bham.ac.uk

1 School of Sport, Exercise and Rehabilitation Sciences, University of Birmingham, Edgbaston, Birmingham B15 2TT, UK

2 Department of Sport and Health Science, Ritsumeikan University, Shiga, Japan

3 Institute of Sports Medicine Copenhagen, Department of Orthopedic Surgery M, Bispebjerg Hospital, Copenhagen, Denmark
4 Clinical Metabolomics Core Facility, Department of Clinical Biochemistry, Rigshospitalet, Copenhagen, Denmark

5 Department of Biomedical Sciences, Faculty of Health and Medical Sciences, University of Copenhagen, Copenhagen, Denmark 


$\begin{array}{ll}\text { Abbreviations } \\ \text { mTORC1 } & \text { Mammalian target of rapamycin complex 1 } \\ \text { CDX } & \text { Cluster dextrin } \\ \text { iAUC } & \text { Incremental area under the curve } \\ \text { T }_{\text {max }} & \text { Time to reach maximum concentration } \\ \text { DXA } & \text { Dual X-ray absorptiometry } \\ \text { FFM } & \text { Fat-free mass } \\ \text { BMI } & \text { Body mass index } \\ \text { RM } & \text { Repetition maximum } \\ \text { GLC } & \text { Glucose } \\ \text { PTC } & \text { Phenylthiocarbamyl } \\ \text { LC-MS/MS } & \text { Liquid chromatography tandem mass } \\ & \text { spectrometer } \\ \text { ELISA } & \text { Enzyme-linked immunosorbent assay } \\ \text { NAP } & \text { N-Acetyl-propyl } \\ \text { GC-C-IRMS } & \text { Gas chromatography combustion isotope } \\ & \text { ratio mass spectrometry } \\ \text { p70S6K } & \text { 70 KDa S6 protein kinase } \\ \text { 4E-BP1 } & \text { Eukaryotic initiation factor 4E-binding } \\ & \text { protein } \\ \text { Akt } & \text { Protein kinase B } \\ \text { rps6 } & \text { Ribosomal protein S6 } \\ \text { eEF2 } & \text { Eukaryotic elongation factor 2 } \\ \text { FSR } & \text { Fractional synthetic rate } \\ \text { BCAA } & \text { Branched-chain amino acids } \\ \text { EAA } & \text { Essential amino acid } \\ \text { TTR } & \text { Tracer to tracee ratio } \\ \text { MPE } & \text { Mole percent excess } \\ \text { IU } & \text { International unit } \\ & \end{array}$

\section{Introduction}

Protein intake is essential for skeletal muscle protein adaptation to resistance exercise training [1]. Muscle protein synthesis is maximally stimulated when exercise is combined with protein ingestion [2-4]. Essential amino acids (EAA) have been shown to be potent in stimulating muscle protein synthesis $[5,6]$. Mechanistically, leucine, one of the branched-chain amino acids (BCAA), is a potent stimulator of mammalian target of rapamycin complex 1 (mTORC1), which is a serine/threonine kinase regulating the translation and initiation [7-9]. Further, the availability of leucine and other essential amino acids $[10,11]$ and the achievement of higher peak aminoacidemia $[12,13]$ are associated with an increase in the rate of muscle protein synthesis, suggesting the importance of quick absorption and rise in essential amino acid availability in the circulation to induce muscle protein synthesis $[12,14]$.

Carbohydrate is often added to protein supplementations for various reasons, such as increasing energy intake, providing readily available substrate for energy metabolism, and improving taste. However, the uptake rate of exogenous amino acids and their availability in circulation is attenuated when consumed with carbohydrate [15-17] or a mixed macronutrients meal $[18,19]$. This is due to a decrease in the rate of digestion and absorption [16] and an increase in the retention of amino acids in the portal drained viscera [20]. In addition, amino acid availability in the circulation is reduced by suppression of protein breakdown [21, 22]. Although plasma insulin concentration was greater when protein was ingested with carbohydrate [15-17] or a mixed meal [18], muscle protein synthesis was not augmented as compared to protein intake alone [15-17]. A systematic review concluded that a systemic administration of insulin does not have a stimulatory or inhibitory effect for muscle protein synthesis and that amino acid availability dictates muscle protein synthesis in healthy younger individuals [23]. Thus, the current evidence does not provide the interactive effect of carbohydrate co-ingestion with protein to augment muscle protein synthesis. However, if the addition of carbohydrate delays the availability of amino acids in the circulation, it could be speculated that carbohydrate would result in a delayed increase in muscle FSR, as observed in slower digestible proteins [13].

Cluster dextrin (CDX) is a branched carbohydrate produced from waxy maize starch by the cyclization of a branching enzyme [24]. CDX is highly soluble in water, has low viscosity, and has a relatively low tendency for retrogradation [25] compared to commercial dextrin [26]. CDX has also been shown to increase the rate of gastric emptying compared to glucose (GLC) and standard dextrin due to a lower osmotic pressure [27]. Accordingly, the rapid gastric emptying of CDX might alleviate the lower amino acid availability when co-ingested with protein as compared to GLC. Thus, a measurement of exogenous protein-derived amino acid availability (i.e., a downstream measurement of digestion and absorption) is required to determine whether co-ingestion of CDX increases amino acid availability for the periphery.

Therefore, we hypothesized that the appearance of amino acids from orally ingested meat protein hydrolysate into the circulation would be faster when it is co-ingested with CDX than GLC. Accordingly, we further hypothesized that the ingestion of the meat protein hydrolysate with $\mathrm{CDX}$ would result in a greater Akt/mTORC1 signaling response and myofibrillar FSR following an acute bout of whole-body resistance exercise as compared to GLC in moderately trained younger males.

\section{Methods}

\section{Ethical approval}

This study was approved by the Ethics Committee of the Capital Region (H-17017363) and adhered to the Helsinki 
II declaration. Before inclusion, each participant was informed of the purpose of the study, experimental procedures, and potential risks prior to obtaining written informed consent. This trial was registered at clinicaltrails.gov as NCT03303729.

\section{Subjects}

Ten moderately trained healthy males $(21.5 \pm 2.1$ years, $22.9 \pm 2.1 \mathrm{~kg} / \mathrm{m}^{2}$; values are mean $\pm \mathrm{SD}$ ) volunteered to participate in a double-blinded, randomized controlled crossover study. Inclusion criteria were as follows: healthy men who conduct structured whole-body resistance training between 1 and 3 times (1-3 h) per week on average over the last 3 months. Exclusion criteria were as follows: subjects younger than 18 years or above 30 years of age, BMI $>30$, smoking, active cancer, renal diseases, diabetes mellitus, vegetarian, physical inactivity (i.e., no systematized exercise), and perform systematized resistance exercise more than 3 times per week. Baseline subject characteristics are presented in Table 1.

\section{Study overview}

This was a double-blinded randomized controlled crossover trial conducted at The Institute of Sports Medicine Copenhagen (ISMC), Bispebjerg Hospital. The overall timeline of the study is shown in Fig. 1a, and a CONSORT flowchart diagram is displayed in Fig. 2. Briefly, at least 2 weeks prior to the first trial, subjects underwent preliminary assessments. The two experimental trials were separated by at least 2 weeks to minimize any interaction on the second trial from the previous trial. On both trial days, the participants arrived in an overnight fasted state at 08:00 h at The Institute of Sports Medicine Copenhagen (ISMC), Bispebjerg Hospital. Personnel with no direct involvement in the experiment rolled dice and created a scheme where the order of the interventions (CDX or GLC) was in code

Table 1 Baseline subject characteristics

\begin{tabular}{lc}
\hline Age, $\mathrm{y}$ & $21.5 \pm 2.1$ \\
Height, $\mathrm{m}$ & $1.82 \pm 0.54$ \\
Body mass, kg & $75.7 \pm 7.6$ \\
FFM, kg & $60.4 \pm 5.4$ \\
BMI, kg/m² & $22.9 \pm 2.1$ \\
1-RM leg press, kg & $283.0 \pm 50.6$ \\
1-RM leg extension, kg & $116.5 \pm 12.1$ \\
10-RM shoulder press, kg & $50.6 \pm 4.5$ \\
10-RM pulldown, kg & $56.5 \pm 9.0$ \\
\hline
\end{tabular}

All values are presented as means \pm SD. $n=10$

FFM fat free mass, $B M I$ body mass index for each subject. On the day of an experiment, the personnel prepared the designated intervention and handed it over to the investigator (MJ). Thus, the allocation of interventions was concealed from the participants and the study investigator until the completion of data analysis. In each experimental visit, muscle biopsies and blood samples were obtained during a primed-continuous stable isotope amino acid infusion $\left({ }^{15} \mathrm{~N}\right.$-phenylalanine) to determine amino acid availability from orally ingested intrinsically labelled meat protein hydrolysate $\left(\mathrm{D}_{5}\right.$-phenylalanine), myofibrillar muscle protein synthesis, and intracellular signaling in response to a whole-body resistance exercise and the intake of meat protein hydrolysate with either GLC or CDX.

\section{Preliminary assessments}

\section{Body mass and height}

Height was measured in the upright position without shoes against a wall and body weight was measured on a digital scale (Seca 719, Seca gmbh \& co., Hamburg, Germany) in light clothing.

\section{Body composition}

Dual X-ray absorptiometry (DXA) was performed to determine the whole-body fat free mass (FFM) by using the enCORE v.16 software (Lunar iDXA; GE Medical Systems, Pewaukee, WI, USA) after having emptied their bladder. DXA scans were performed after at least $12 \mathrm{~h}$ overnight fast.

\section{Strength tests}

After the scanning, strength was assessed by leg press, knee extension (Super Executive Line, TechnoGym, Gambettola, Cesana, Italy), shoulder press (TR Equipment model 9025, Tranås, Sweden) and shoulder pull/pull-down (Lat Mach, TechnoGym, Gambettola, Cesana, Italy) strength exercise machines. The strength tests were 1 repetition maximum (RM) and 10RM for leg exercises and upper body exercises, respectively. The 10RM test for the upper body exercises was chosen to minimize any risk of injury by unaccustomed exercises during testing.

\section{Experimental protocol}

The experimental protocol is shown in Fig. 1b. The overall experimental protocol consisted of a primed $(4.0 \mu \mathrm{mol} *$ $\left.\mathrm{kg} \mathrm{FFM}^{-1}\right)$ continuous $\left(3.8 \mu \mathrm{mol} * \mathrm{~kg} \mathrm{FFM}^{-1} *\right.$ hour $\left.^{-1}\right)$ infusion of L-[ $\left.{ }^{15} \mathrm{~N}\right]$-phenylalanine, which was applied over the course of the experimental trial. The participants rested in the supine position for the remainder of the trial day, only interrupted by the training program and toilet 
a

Preliminary assessment

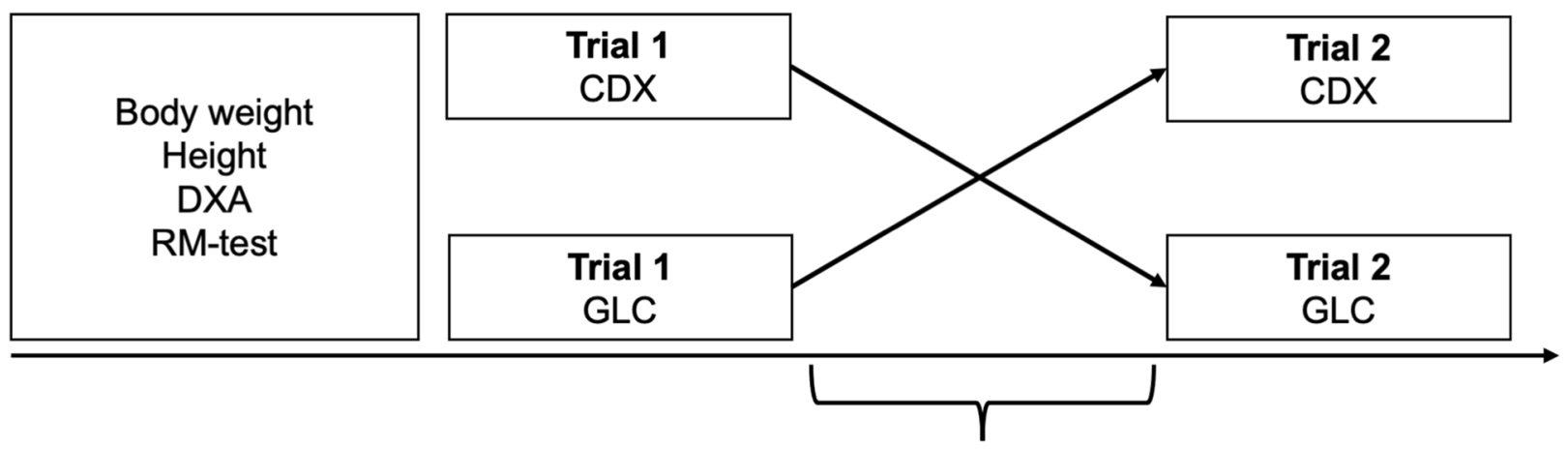

$\geq 14$ days washout

b

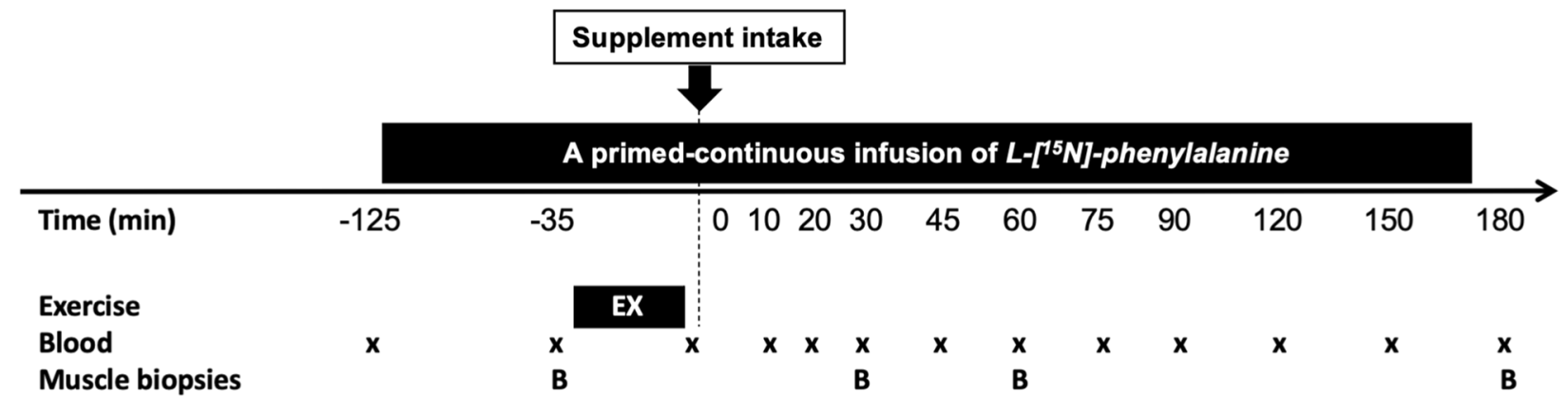

Fig. 1 Schematic overview of crossover study design (a) and experimental protocol (b). DXA dual X-ray absorptiometry; RM repetition maximum, $E X$ exercise, $B$ muscle biopsy, $G L C$ glucose, CDX cluster dextrin

visits. Two antecubital catheters were inserted into each arm of the participant, one for the infusion of a stable isotope amino acid tracer $\left({ }^{15} \mathrm{~N}\right.$-phenylalanine $)$ and the other for serial blood sampling. A background blood sample was drawn after which the primed continuous infusion was started. The subject rested for approximately $1.5 \mathrm{~h}$ after which the first biopsy was taken, and a blood sample was drawn. The leg and site of the biopsies were randomized using dice. Hereafter, the participant walked a small distance of $100 \mathrm{~m}$ to the training facility where they conducted the resistance exercise program under full guidance and supervision (see Resistance exercise protocol). Upon completion, the participant walked back to the trial room where a post-exercise blood sample was drawn. Hereafter, an independent research assistant prepared the drink containing the intrinsically labeled $\left(\mathrm{D}_{5}\right.$-phenylalanine) meat protein hydrolysate $\left(0.6 \mathrm{~g}\right.$ protein $\left.* \mathrm{FFM}^{-1}\right)$ mixed with either $75 \mathrm{~g}$ of GLC or CDX in $350 \mathrm{~mL}$ of cold tap water. The drink was consumed in less than 5 min by the participant. Furthermore, the post-exercise drink was enriched with $5 \%{ }^{15} \mathrm{~N}$-phenylalanine to minimize any fluctuations in the serum enrichment after consumption of the protein-rich drink (unlabeled phenylalanine). The amount of meat protein hydrolysate was decided to provide sufficient amino acids following a whole-body resistance exercise. A previous study showed that a higher protein intake is required when a whole-body resistance exercise is performed as compared to a unilateral leg resistance exercise [28]. Nutritional composition of meat protein hydrolysate, CDX, GLC is presented in Table 2. Once the drink was consumed, blood was sampled in a vacutainer coated with $\mathrm{Z}$ serum clot activator (Vacuette tube, Greiner Bio-One GhmB, Austria) at 10, 20, 30, 45, 60, 75, 90, 120, 150, and 180 min following the post-exercise drink. Muscle biopsies were taken from the vastus lateralis at 30,60 , and 180 min post drink under local anesthesia (1\% lidocaine) using the Bergström technique [29]. Muscle samples were rinsed in ice-cold saline $(9 \mathrm{mg} / \mathrm{ml})$ and freed from any visible blood and connective tissues before being snap frozen in liquid nitrogen and stored at $-80{ }^{\circ} \mathrm{C}$ for future analysis. After the last biopsy, the infusion was stopped, catheters were removed, and the participant was given a sandwich before being sent home. 


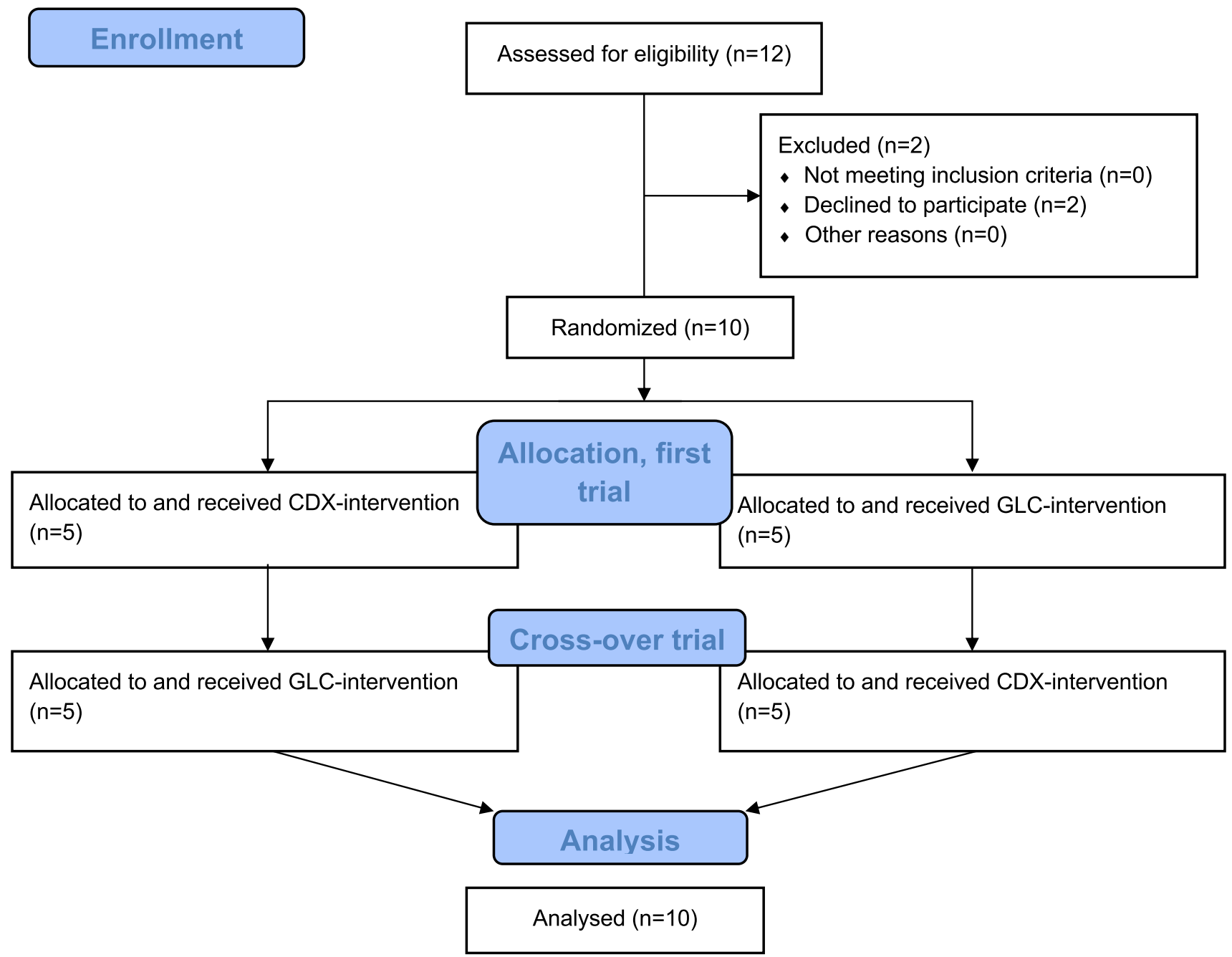

Fig. 2 A CONSORT flowchart diagram

\section{Resistance exercise protocol}

The resistance exercise session consisted of four different exercises for both the lower and upper body and was the same as those used in the preliminary assessment: leg press, knee extension, shoulder press and shoulder pull/pull down. The subjects completed 3 sets of 8 repetitions at $70 \%$ of $1 \mathrm{RM}$ in each of the two leg exercises and 3 sets of 10 reps at 10RM in the two upper body exercises. Three sets of each exercise were completed before conducting the next exercise. Rest periods of 2 min were allowed between sets and exercises.

\section{Meat protein hydrolysate}

The meat, from which the hydrolysate has been produced, had been intrinsically labeled with ring- $\mathrm{D}_{5}$-phenylalanine by infusing Holstein cows with the ring- $\mathrm{D}_{5}$-phenylalanine tracer for $72 \mathrm{~h}$ before slaughter [18]. The meat protein hydrolysate is quickly absorbed and induces an immediate and high availability of amino acids in the circulation after a bolus intake [18]. This allows to directly measure the availability of the orally consumed meat protein hydrolysate-derived amino acids in the circulation.

\section{Blood analysis}

Blood was sampled with vials coated with $\mathrm{Z}$ serum clot activator and left at room temperature for $30 \mathrm{~min}$ before being centrifuged $\left(3,970 \mathrm{x} \mathrm{g}, 10 \mathrm{~min}, 4{ }^{\circ} \mathrm{C}\right)$ in an Eppendorf 5810R (Eppendorf AG, Hamburg, Germany) to obtain serum. Serum samples were stored at $-80{ }^{\circ} \mathrm{C}$ for further analysis.

Serum amino acid concentrations were determined as described in detail elsewhere [30]. We used $100 \mu \mathrm{L}$ of the serum, which was added internal standards for all amino acids and were acidified with the addition of $120 \mu \mathrm{L}$ of $50 \%$ acetic acid before being poured over columns (Medium HDPE Open tip column CC07, Intertech Medical Inc., 
Table 2 Nutritional composition of meat protein hydrolysate, cluster dextrin (CDX), and glucose (GLC)

\begin{tabular}{|c|c|c|c|}
\hline & $\begin{array}{l}\text { Meat protein hydrolysate } \\
(0.6 \mathrm{~g} \text { protein/ FFM kg })^{1}\end{array}$ & CDX & GLC \\
\hline Total served weight, $\mathrm{g}$ & 300 & 75 & 75 \\
\hline Energy, kcal & 162 & 300 & 300 \\
\hline Protein, g & 36 & - & - \\
\hline Protein, kcal & 144 & - & - \\
\hline Fat, g & 1.8 & - & - \\
\hline Fat, kcal & 16.2 & - & - \\
\hline Carbohydrate, $g$ & 0 & 75 & 75 \\
\hline Carbohydrate, kcal & 0 & 300 & 300 \\
\hline Alanine, $g$ & 2.04 & - & - \\
\hline Arginine, $g$ & 2.06 & - & - \\
\hline Aspartic acid, g & 3.27 & - & - \\
\hline Cysteine, g & 0.28 & - & - \\
\hline Glutamic acid, g & 5.46 & - & - \\
\hline Glycine, g & 1.46 & - & - \\
\hline Histidine, $g$ & 1.36 & - & - \\
\hline Isoleucine, $\mathrm{g}$ & 1.61 & - & - \\
\hline Leucine, $g$ & 2.86 & - & - \\
\hline Lysine, $g$ & 3.21 & - & - \\
\hline Methionine, $\mathrm{g}$ & 0.80 & - & - \\
\hline Phenylalanine, $g$ & 1.54 & - & - \\
\hline Proline, g & 1.27 & - & - \\
\hline Serine, $\mathrm{g}$ & 1.37 & - & - \\
\hline Threonine, $\mathrm{g}$ & 1.61 & - & - \\
\hline Tryptophan, g & 0.42 & - & - \\
\hline Tyrosine, $g$ & 1.17 & - & - \\
\hline Valine, $\mathrm{g}$ & 1.74 & - & - \\
\hline $\begin{array}{l}\text { Total essential amino acids, } \\
\mathrm{g}\end{array}$ & 15.16 & - & - \\
\hline Total amino acids, $g$ & 33.55 & - & - \\
\hline $\begin{array}{l}\mathrm{D}_{5} \text {-phenylalanine } \\
\text { enrichment }^{2}, \mathrm{MPE} \pm \mathrm{SD}\end{array}$ & $0.73 \pm 0.01$ & - & - \\
\hline
\end{tabular}

$C D X$ cluster dextrin, GLC glucose, $M P E$ mole percent excess, $S D$ standard deviation

${ }^{1}$ For an individual with 60 fat free mass (FFM) kg

${ }^{2}$ Value was reported by Reitelseder et al. [18]

Denver, CO) containing acidified cation exchange resin (Dowex AG $50 \mathrm{~W}-\mathrm{X} 8$ resin 100-200 mesh, BioRad, Copenhagen, Denmark). Purified amino acids were converted to their phenylthiocarbamyl (PTC) derivatives, by adding a coupling buffer (methanol: Milli-Q ${ }^{\circledR}$ water:triethylamin $(2: 2: 1, \%, v / v))$, drying at $70{ }^{\circ} \mathrm{C}$ under a flow of $\mathrm{N}_{2}$, adding the derivatization solution (triethylamin: Milli- ${ }^{\circledR}$ water:PITC:methanol $(1: 1: 1: 7, \%, \mathrm{v} / \mathrm{v}))$. Then, the sample was vortexed and incubated at room temperature for $30 \mathrm{~min}$. Hereafter, the solution was dried at $70{ }^{\circ} \mathrm{C}$ under a flow of $\mathrm{N}_{2}$ and acetonitrile, methanol, and Milli-Q ${ }^{\circledR}$ purified water (44:10:46, \%, v/v) with $0.1 \mathrm{M}$ ammonium acetate was added.
The isotope ratios of $\mathrm{D}_{5^{-}}$and ${ }^{15} \mathrm{~N}$-phenylalanine and a full amino acid concentration profile were determined on a liquid chromatography-tandem mass spectrometer (LC-MS/MS; triple stage quadrupole mass spectrometer, TSQ Vantage, Thermo Fischer Scientific, San Jose, CA, USA).

Serum insulin concentrations were measured using a high-sensitivity human insulin enzyme-linked immunosorbent assay (ELISA) kit (DRG Instrument $\mathrm{GmbH}$ ) at the time points $-35,0,10,20,30,45,60,90,120$, and $180 \mathrm{~min}$.

\section{Muscle tissue analyses}

\section{Intramuscular amino acid concentration}

From $10 \mathrm{mg}$ of wet weight muscle, BCAA concentrations were determined using the same protocol as for serum amino acids as described above [30]. Briefly, the frozen muscle specimens were homogenized in $1 \mathrm{ml}$ of $6 \%$ perchloric acid with an added internal standard for the determination of BCAA concentrations. The samples were spun down and the supernatant containing the tissue free amino acids was extracted. The samples were then poured over acidified cation exchange columns with resin (AG $50 \mathrm{~W}-\mathrm{X} 8$ resin, BioRad laboratories, Hercules, $\mathrm{Ca}$, USA). The amino acids were eluted with $2 \times 2 \mathrm{ml}_{4} \mathrm{M} \mathrm{NH}_{4} \mathrm{OH}$ and derivatized into their phenylthiocabamyl (PTC) derivative. Derivatized samples were loaded and analyzed on LC-MS/MS (Thermo Fischer Scientific, San Jose, CA, USA). Each intramuscular BCAA concentration was normalized to the wet weight of muscle used to prepare for the analysis. The intramuscular water fraction was set as 0.77 of the muscle wet weight.

\section{Myofibrillar protein bound tracer enrichments}

From $20 \mathrm{mg}$ of wet weight muscle, the abundance of myofibrillar protein bound ${ }^{15} \mathrm{~N}$-phenylalanine was measured according to our lab's standard protocol. Briefly, the frozen muscle specimen was homogenized in $1 \mathrm{~mL}$ of buffer (Tris $0.02 \mathrm{M}$ [pH 7.4], $\mathrm{NaCl} 0.15 \mathrm{M}$, EDTA $2 \mathrm{mM}$, EGTA $2 \mathrm{mM}$, TritonX-100 $0.5 \%$, sucrose $0.25 \mathrm{M}$ ) for $4 \times 45 \mathrm{~s}$, speed 5.5 (FastPrep 120A-230; Thermo Savant, Holbrook, NY, USA) and left at $5{ }^{\circ} \mathrm{C}$ for $3 \mathrm{~h}$. Hereafter, samples were centrifuged at $800 \mathrm{~g}$ for $20 \mathrm{~min}$ at $5{ }^{\circ} \mathrm{C}$. The supernatant was discarded, and $1 \mathrm{~mL}$ of homogenization buffer was added, homogenized for $45 \mathrm{~s}$ at speed 5.5 , incubated at $5{ }^{\circ} \mathrm{C}$ for $30 \mathrm{~min}$, and centrifuged. The supernatant was discarded, and $1.5 \mathrm{~mL}$ buffer $\left(\mathrm{KCl} 0.7 \mathrm{M}\right.$, pyrophosphate $\left(\mathrm{Na}_{4} \mathrm{P}_{2} \mathrm{O}_{7}\right)$ $0.1 \mathrm{M}$ ) was added to the pellet, vortexed and left overnight at $5{ }^{\circ} \mathrm{C}$. The day after, the samples were spun at $1,600 \mathrm{x} \mathrm{g}$ for $20 \mathrm{~min}$ at $5{ }^{\circ} \mathrm{C}$ and the supernatant transferred to glass vials suitable for hydrolysis and added $2.3 \times$ vol ethanol $99 \%$, vortexed and left for $2 \mathrm{~h}$ at $5{ }^{\circ} \mathrm{C}$, and subsequently spun at $1,600 \mathrm{x}$ g for $20 \mathrm{~min}$. The supernatant was then discarded, 
and $1 \mathrm{~mL}$ of $70 \%$ ethanol was added to the pellet, after which the solvent was vortexed and centrifuged at $1,600 \mathrm{xg}$ for $20 \mathrm{~min}$. The supernatant was discarded and $1 \mathrm{~mL}$ of $1 \mathrm{M}$ $\mathrm{HCl}$ and $1 \mathrm{~mL}$ of resin slurry was added to the pellet and left overnight at $110^{\circ} \mathrm{C}$. The solvent was diluted with water and the amino acids were purified over cation exchange resin columns. The purified amino acids were derivatized as their $\mathrm{N}$-acetyl-propyl (NAP) derivate and analyzed on gas chromatograph-combustion-isotope ratio mass spectrometer by following standard procedure described thoroughly by Bornø et al. [31].

\section{Intracellular signaling}

Western blotting was performed as reported previously with a slight modification [32]. Briefly, approximately $\sim 30 \mathrm{mg}$ of frozen muscle tissue samples was homogenized in tenfold volumes of RIPA buffer (Cell Signaling Technology, Danvers, MA, USA) supplemented with protease and phosphatase inhibitor cocktail (Roche Life Science, Indianapolis, IN, USA) per $10 \mathrm{~mL}$ of homogenization buffer. The resulting homogenates were centrifuged at $14,000 \mathrm{x}$ g for $10 \mathrm{~min}$ at $4{ }^{\circ} \mathrm{C}$. The supernatant was transferred to a new vial and total protein concentrations were determined by the Protein Assay Rapid kit (WAKO, Osaka, Japan). The samples were standardized to $2 \mu \mathrm{g}$ protein per $1 \mu \mathrm{L}$ by dilution with $3 \times$ SDS sample buffer containing $15 \% \beta$-mercaptoethanol, $6 \%$ SDS, $187.5 \mathrm{mM}$ Tris- $\mathrm{HCl}$ (pH 6.8), 15\% sucrose, and $0.015 \%$ bromophenol blue and boiled at $95{ }^{\circ} \mathrm{C}$ for $5 \mathrm{~min}$. An equal amount of protein $(10 \mu \mathrm{g})$ was loaded into each lane and the samples were separated by electrophoresis on a 10 or $15 \%$ SDS-polyacrylamide gel for $45 \mathrm{~min}$ at $250 \mathrm{~V}$. Following electrophoresis, proteins were transferred to a polyvinylidene fluoride (PVDF) membrane for $1 \mathrm{~h}$ at $20 \mathrm{~V}$ via a semi-dry transfer. Membranes were subsequently blocked in $5 \%$ milk for $1 \mathrm{~h}$ at room temperature. After blocking, membranes were washed 3 times for $5 \mathrm{~min}$ in Tris-buffered saline with $0.1 \%$ Tween (TBST) before being incubated overnight at $4{ }^{\circ} \mathrm{C}$ in primary antibody against phospho-70 kDa S6 protein kinase (p70S6K) Thr389 (\#9234), total p70S6K (\#2708), phospho-eukaryotic initiation factor 4E-binding protein (4E-BP1) Thr37/46 (\#9459), total 4E-BP1 (\#9452), phospho-protein kinase B (Akt) Ser473 (\#9271), total Akt (\#2920), phospho-AMPK $\alpha$ Thr172 (\#2535), total AMPK $\alpha$ (\#2793), phospho-ribosomal protein S6 (rps6) Ser240/244 (\#2215), total rps6 (\#2217), phospho-eukaryotic elongation factor 2 (eEF2) Thr56 (\#2331), total eEF2 (\#2332) each purchased from Cell Signaling Technology (Danvers, MA, USA). Membranes were then washed again 3 times for $5 \mathrm{~min}$ in TBST and incubated for $1 \mathrm{~h}$ in their respective secondary antibody at room temperature and washed again 3 times for 5 min in TBST. Chemiluminescence (Luminata 200 Forte Western HRP Substrate; Merck Millipore, Temecula, CA,
USA) was applied to each blot. Images were developed using an ImageQuant LAS 4000 (GE Healthcare, Amersham, UK). Band intensities were quantified using Image Studio Lite (Li-Cor, Lincoln, Nebraska, USA). Phosphorylation levels were determined by the expression of phosphorylated protein divided by the expression of non-phosphorylated total protein. The membranes were stained with Ponceau-S to verify equal loading and used as the normalization control.

\section{Calculations}

FSR was calculated using the precursor-product method [33]:

$\mathrm{FSR}=\frac{\mathrm{E}_{2}-E_{1}}{\mathrm{e}_{t 1-t 2} * t_{1-2}} * 100$,

where $\mathrm{E}$ is the protein bound enrichment, é is precursor enrichment between two samples estimated from venous serum samples and $t$ is the time between two samples. The FSR will be calculated from 30 to $180 \mathrm{~min}$ post exercise.

\section{Statistical analysis}

To compare the effect of time within each of the two trials and the two dependent trials (GLC versus CDX), we applied a 2-factor [time $\times$ group (GLC compared with CDX)] repeated measures ANOVA when no missing data appeared and a mixed-effects model when data points were missing (insulin concentration measures; one data point was missing (Subject\#1, CDX trial, time point 180 min). Turkey's multiple comparisons test was used as a post hoc test to identify the individual differences when there was a time $\times$ group interaction effect, a main effect of time, or a main effect of group. Paired student two-tailed $t$-test was used to compare postprandial (0.5-3 h) FSR between CDX and GLC trials, incremental area under the curve (iAUC), and time to reach maximum concentration $\left(T_{\max }\right)$ for serum $\mathrm{D}_{5}$-phenylalanine enrichments and serum phenylalanine, EAA, BCAA, and insulin concentrations. iAUC is the definite integral of a curve that depicts the serum parameters as a function of time during the postprandial period using the value for the parameter at time point zero as the baseline value. iAUC was computed using the trapezoid rule. A straight line is connected between adjunct points, and the beneath area was calculated as $\Delta \mathrm{X}^{*}([(\mathrm{Y} 1+\mathrm{Y} 2) / 2]-$ Baseline $]$. This was repeated for each region, and the sum of the areas was defined as iAUC. $T_{\max }$ was obtained from the concentration-time data, where the time of the highest concentration of serum parameters was observed during the postprandial period. A priori power analysis was performed for a matched paired $t$-test (two tails) with an $\alpha$ error probability $=0.05$, power $(1-\beta$ error probability $)=0.8$, and Cohen's effect size $\mathrm{dz}=1.0$ using 


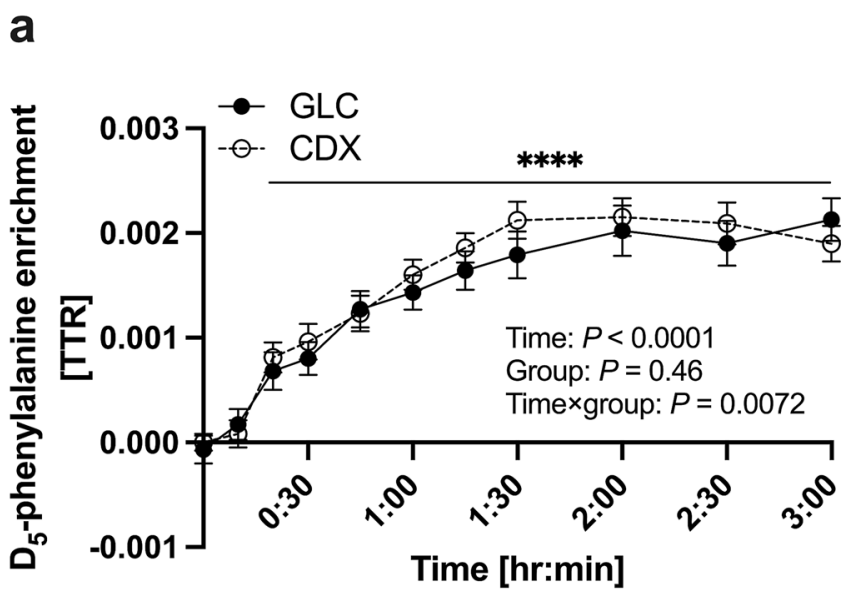

C

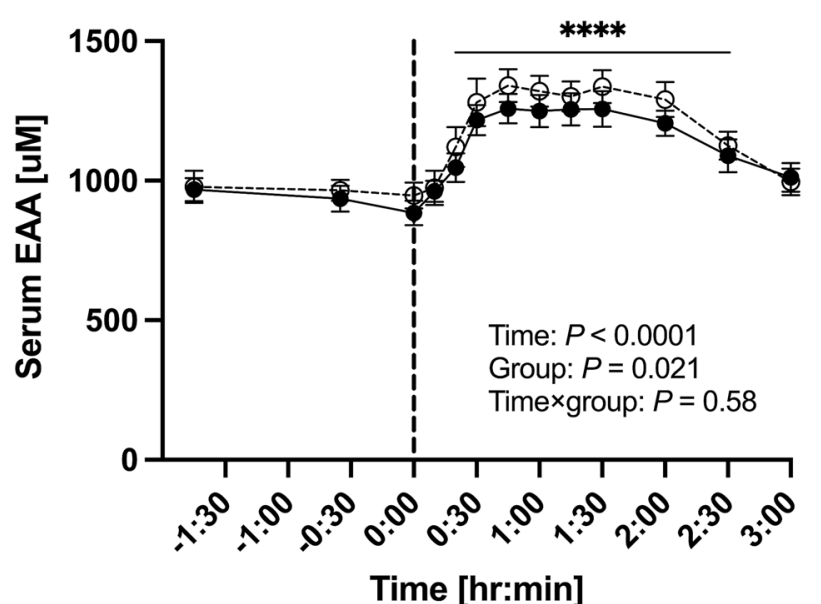

e

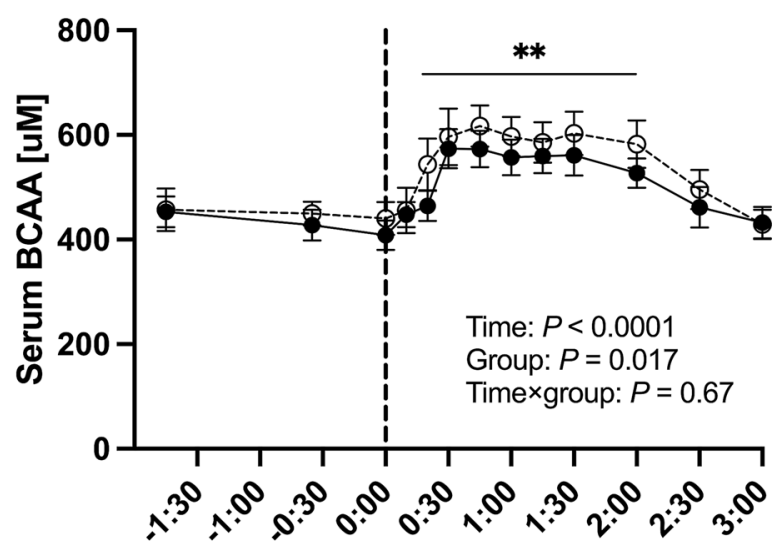

Time [hr:min]

G*Power version 3.1 analysis software (Heinrich Hein University). Cohen's effect size $\mathrm{dz}=1.0$ was calculated based on the least detectable difference of $0.01 \% / \mathrm{h}$ FSR between groups and the within subject standard deviation of $0.01 \% / \mathrm{h}$. b

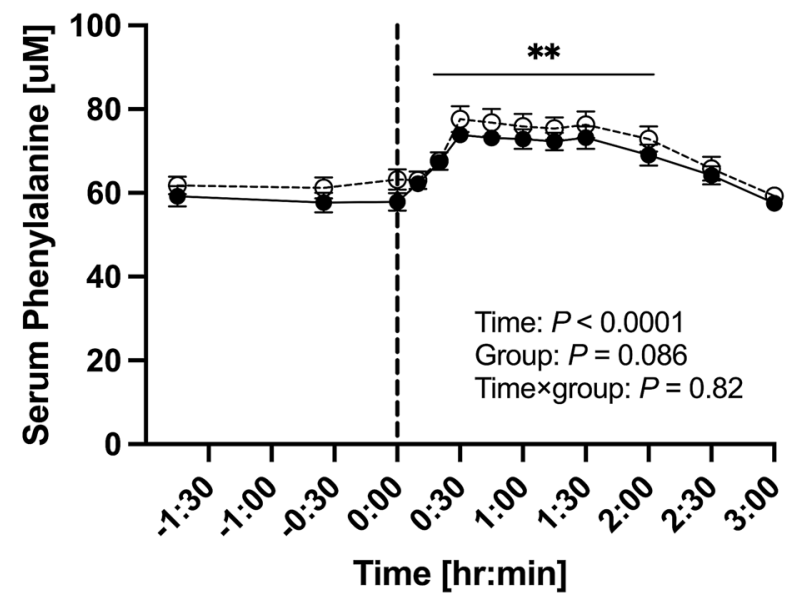

d

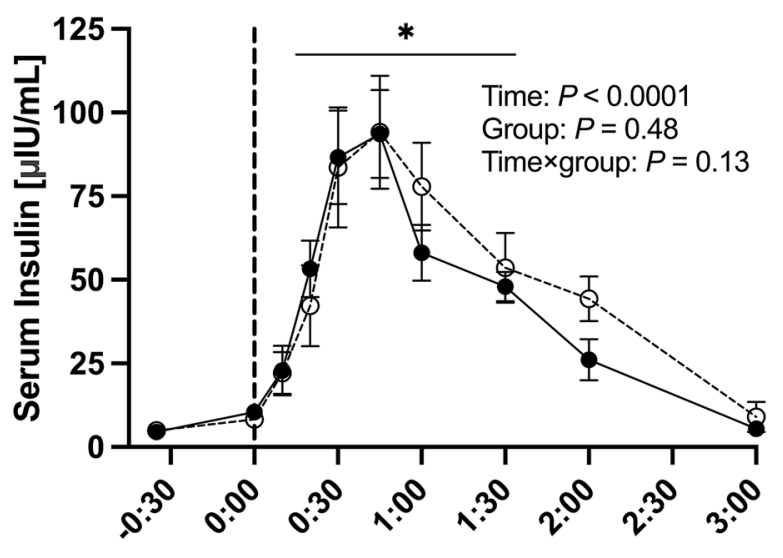

Time [hr:min]

f

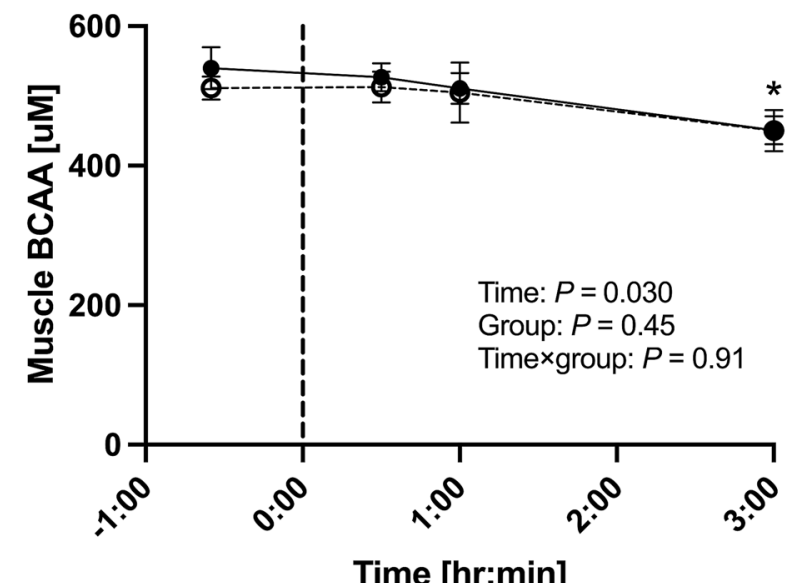

Time [hr:min]
This produced a minimum sample size of $n=10$. Data are expressed as means \pm SD or SEM. An alpha level of 0.05 was used to determine statistical significance. All statistical 
4Fig. 3 The time course of serum $\mathrm{D}_{5}$-phenylalanine enrichment (a), phenylalanine (b), EAA (c) insulin (d) BCAA (e) muscle BCAA (f) concentrations. The vertical dot line on each graph (at $t=0)$ indicates the transition from postabsorptive to postprandial conditions via the ingestion of meat protein hydrolysate $\left(0.6 \mathrm{~g}\right.$ protein $\left.* \mathrm{FFM}^{-1}\right)$ with either $75 \mathrm{~g}$ of GLC $(n=10)$ or CDX $(n=10)$ following a whole-body resistance exercise. Data were analyzed with the use of a 2-factor [time $\times$ group (GLC compared with CDX)] ANOVA with Turkey's multiple comparisons test to locate individual differences. Values are means \pm SEM. Significance was set at $P<0.05$. There was a main effect of time for serum $\mathrm{D}_{5}$-phenylalanine enrichment, phenylalanine, EAA, BCAA, insulin concentrations and $(P<0.0001)$ and muscle BCAA $(P<0.05)$. There was a main effect of group (GLC compared with $\mathrm{CDX})$ for serum EAA and BCAA concentrations $(P<0.05)$. There was a time $\times$ group interaction effect for $\mathrm{D}_{5}$-phenylalanine enrichment $(P<0.05)$. *,**, **** denotes significant difference from basal $(P<0.05, P<0.01, P<0.0001$, respectively). TTR tracer to tracee ratio, GLC glucose, $C D X$ cluster dextrin, $B C A A$ branched-chain amino acids

analysis was performed using GraphPad Prism version 8.4.3 for Mac (GraphPad Software, La Jolla California USA).

\section{Results}

\section{Participants}

Baseline subject characteristics are shown in Table 1. Figure 2 shows a CONSORT flow diagram describing the progress from recruitment through completion of the study.

\section{Phenylalanine amino acid tracer enrichment}

Serum $D_{5}$-phenylalanine (Fig. 3a) enrichment originated from intrinsically labeled meat protein hydrolysate was increased following the ingestion of post-exercise drink at $t=0$ (a main effect of time, $P<0.0001$ ) between 20 and $180 \mathrm{~min}(P<0.0001)$. There was no main effect of group for serum $\mathrm{D}_{5}$-phenylalanine enrichment $(P=0.46)$. There was a time $\times$ group interaction effect $(P=0.0072)$. The enrichment of the infused tracer, L-[ring- $\left.{ }^{15} \mathrm{~N}\right]$-phenylalanine (Fig. 4a), was elevated above basal value $(t=0)$ following the tracer infusion 20-180 min (a main effect of time, $P<0.0001)$. There was no main effect of group $(P=0.27)$ and time $\times$ group interaction effect $(P=0.067)$.

\section{Serum amino acid concentrations}

Serum phenylalanine concentrations (Fig. 3b) were increased compared to basal value $(t=0)$ from 20 to $120 \mathrm{~min}(P<0.01)$ following the intake of post-exercise drink (a main effect of time, $P<0.0001)$. There was no main effect of group for serum phenylalanine $(P=0.086)$. Serum EAA concentrations (Fig. 3c) were increased compared to basal value $(t=0)$ from 20 to $150 \mathrm{~min}(P<0.0001)$ following the intake of post-exercise drink (a main effect of time, $P<0.0001$ ). There was a main effect of group for serum EAA $(P=0.021)$. Likewise, serum BCAA concentrations (Fig. 3e) were increased above basal value $(t=0)$ between 20 and $120 \mathrm{~min}(P<0.01)$ with an overall time effect $(P<0.0001)$. There was a main effect of group for serum BCAA concentrations $(P=0.02)$. In contrast, there was a main effect of time $(P<0.05)$ for muscle BCAA concentrations (Fig. 3f), and it was decreased at $180 \mathrm{~min}(P<0.05)$ following the intake of post-exercise drink compared to basal value $(\mathrm{t}=-35 \mathrm{~min})$. There was no main effect of group for muscle BCAA $(P=0.45)$. There was no time $\times$ group interaction effect for serum EAA $(P=0.58)$, phenylalanine $(P=0.82)$, BCAA concentrations $(P=0.67)$, and muscle BCAA concentrations $(P=0.91)$.

\section{Serum insulin concentrations}

Serum insulin concentrations (Fig. 3d) were increased above basal value $(t=0)$ between 20 and $90 \min (P<0.05)$ following the intake of post-exercise drink (an overall time effect, $P<0.0001$ ). There was no main effect of group (GLC compared with CDX) for serum insulin concentrations $(P=0.48)$. There was no time $\times$ group interaction effect for insulin concentrations $(P=0.13)$.

\section{iAUC and $T_{\text {max }}$ in serum parameters}

iAUC and $\mathrm{T}_{\max }$ serum $\mathrm{D}_{5}$-phenylalanine, phenylalanine, EAA, BCAA, and insulin are displayed in Table 3. $\mathrm{T}_{\max }$ serum BCAA was higher in CDX compared to GLC $(P<0.05) . \mathrm{T}_{\max }$ serum EAA showed a trend towards statistical significance favoring CDX over GLC $(P=0.051)$.

\section{Myofibrillar protein fractional synthesis rate}

Postprandial myofibrillar FSR was calculated using the average serum L-[ring- ${ }^{15} \mathrm{~N}$ ]-phenylalanine enrichments as the precursor pool (Fig. 4b). Myofibrillar protein FSR between 30 and 180 min was not different between GLC and CDX $\left(0.0862 \pm 0.0137\right.$ and $0.1026 \pm 0.0093 \% \bullet^{-1}$, respectively, $P=0.17)$.

\section{Intracellular signaling}

The time-dependent changes of intracellular signaling are displayed in Fig. 5 and representative western blot images are shown in Fig. 6. The phosphorylation of p70S6K $\mathrm{K}^{\mathrm{Th}} 389$ (Fig. 5b), rpS6 ${ }^{\text {Ser240/244 }}$ (Fig. 5d), ERK1/2 ${ }^{\text {Thr202/ Tyr204 }}$ (Fig. 5f), AMPK $\alpha^{\text {Thr172 }}$ (Fig. 5g) showed a time $\times$ group interaction effect $(P<0.05)$. There was a main effect of time $(P<0.05)$ for $\mathrm{Akt}^{\mathrm{Ser} 473}$ (Fig. 5a), p70S6K ${ }^{\mathrm{Thr} 389}$ (Fig. 5b), 4E-BP1 ${ }^{\text {Thr37/46 }}$ (Fig. 5c), rpS6 $6^{\text {Ser240/244 }}$ (Fig. 5d), eEF2 ${ }^{\text {Thr56 }}$ (Fig. 5e), ERK $1 / 2^{\text {Thr202/Tyr204 }}$ (Fig. 5f), AMPKo $\alpha^{\text {Thr172 }}$ 
a

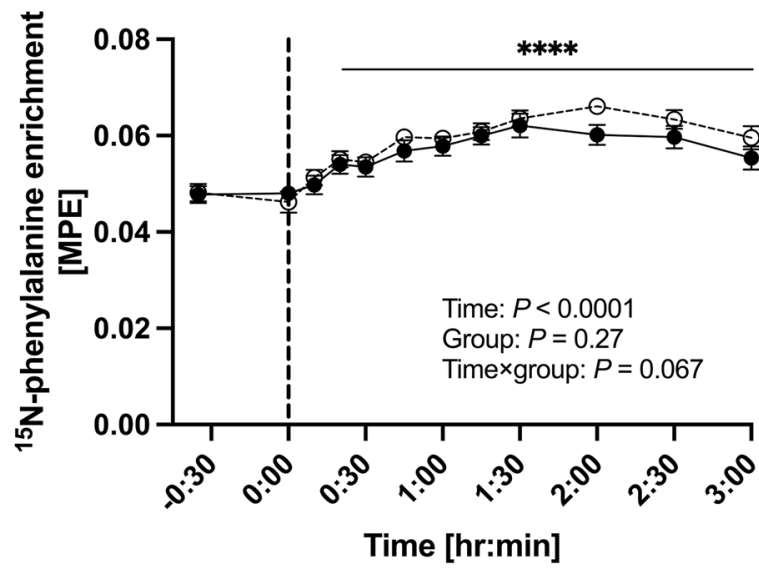

b

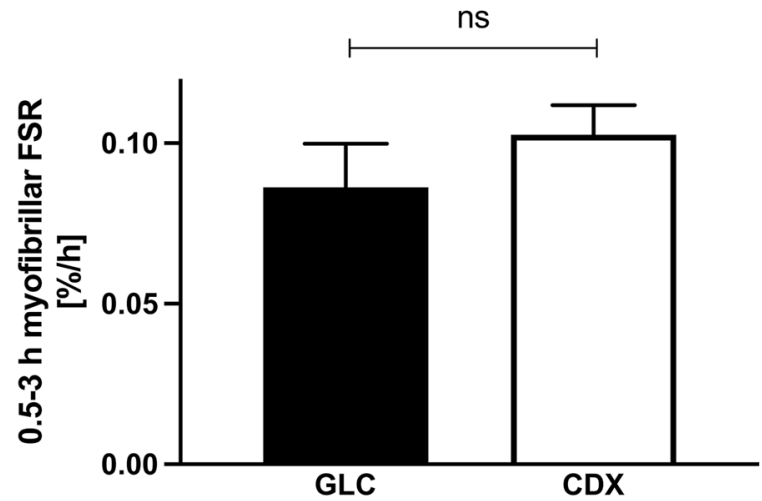

Fig. 4 The time course of serum ${ }^{15} \mathrm{~N}$-phenylalanine enrichment (a) and myofibrillar FSR over a 2.5 -h postprandial period (b). The vertical dot line on each graph (at $t=0$ ) indicates the transition from postabsorptive to postprandial conditions via the ingestion of meat protein hydrolysate $\left(0.6 \mathrm{~g}\right.$ protein $\left.* \mathrm{FFM}^{-1}\right)$ with either $75 \mathrm{~g}$ of GLC $(n=10)$ or CDX $(n=10)$ following a whole-body resistance exercise. Serum ${ }^{15} \mathrm{~N}$-phenylalanine enrichment was analyzed with the use of a 2-factor [time $\times$ group (GLC compared with CDX)] ANOVA with Turkey's multiple comparisons test to locate individual differences. Values are means \pm SEM. Significance was set at $P<0.05$. There was a main effect of time for serum ${ }^{15} \mathrm{~N}$-phenylalanine enrichment $(P<0.0001)$. Myofibrillar FSR was analyzed with the use of a paired $t$-test (twotailed). $n=10 /$ group. Values are means \pm SEM. Significance was set at $P<0.05$. Analysis revealed no statistical difference between GLC and $\operatorname{CDX}(P=0.17)$. MPE mole percent excess, FSR fractional synthesis rate, $G L C$ glucose, $C D X$ cluster dextrin

(Fig. 5g). There was a main effect of group $(P<0.05)$ for $\mathrm{Akt}^{\mathrm{Ser} 473}$ (Fig. 5a), p70S6K ${ }^{\text {Thr389 }}$ (Fig. 5b), rpS6 ${ }^{\mathrm{Ser} 240 / 244}$ (Fig. 5d), ERK1/2 Thr202/Tyr204 (Fig. 5f). The phosphorylation of $\mathrm{Akt}^{\mathrm{Ser} 473}$ (Fig. 5a) was increased from baseline at all time points $(P<0.05)$. The phosphorylation of $\mathrm{p} 70 \mathrm{~S} 6 \mathrm{~K}^{\mathrm{Th} 389}$ (Fig. 5b) was increased from baseline at $30 \mathrm{~min}$ and $60 \mathrm{~min}$ in CDX $(P<0.05)$, and it was greater in CDX $(83.8$-fold $)$ than GLC $(18.3$-fold $)$ at $60 \mathrm{~min}(P<0.05)$. The phosphorylation of 4E-BP $1^{\text {Thr37/46 }}$ (Fig. 5c) was increased from baseline at $30 \mathrm{~min}$ and $60 \mathrm{~min}(P<0.05$ and $P<0.0001$, respectively). The phosphorylation of $\mathrm{rpS}^{\mathrm{Ser} 240 / 244}$ (Fig. 5d)
Table 3 iAUC and $T_{\max }$ serum $\mathrm{D}_{5}$-phenylalanine, phenylalanine, EAA, BCAA, and insulin in response to meat protein hydrolysate intake with either GLC or CDX

\begin{tabular}{|c|c|c|c|}
\hline & GLC & CDX & $P$ value \\
\hline \multicolumn{4}{|c|}{$\mathrm{D}_{5}$-phenylalanine enrichment } \\
\hline iAUC, TTR min & $0.0048 \pm 0.00033$ & $0.0050 \pm 0.00029$ & 0.46 \\
\hline $\mathrm{T}_{\max }, \min$ & $133.5 \pm 13.5$ & $120 \pm 11.0$ & 0.51 \\
\hline \multicolumn{4}{|l|}{ Phenylalanine } \\
\hline iAUC, $\mu \mathrm{M}$ min & $32.1 \pm 2.3$ & $27.0 \pm 2.9$ & 0.099 \\
\hline $\mathrm{T}_{\max }, \min$ & $75.0 \pm 7.7$ & $69.0 \pm 11.7$ & 0.68 \\
\hline \multicolumn{4}{|l|}{ EAA } \\
\hline iAUC, $\mu \mathrm{M}$ min & $825.2 \pm 54.6$ & $810.1 \pm 64.2$ & 0.84 \\
\hline $\mathrm{T}_{\max }, \min$ & $84.0 \pm 7.8$ & $64.5 \pm 9.8$ & 0.051 \\
\hline \multicolumn{4}{|l|}{ BCAA } \\
\hline iAUC, $\mu \mathrm{M}$ min & $335.8 \pm 24.7$ & $342.4 \pm 37.4$ & 0.87 \\
\hline $\mathrm{T}_{\max }, \min$ & $70.5 \pm 11.0$ & $47.0 \pm 8.0$ & $0.049 *$ \\
\hline \multicolumn{4}{|l|}{ Insulin } \\
\hline iAUC, $\mu I U / m L$ min & $94.6 \pm 10.8$ & $119.0 \pm 17.4$ & 0.098 \\
\hline $\mathrm{T}_{\max }, \min$ & $51.0 \pm 8.4$ & $39.5 \pm 3.7$ & 0.29 \\
\hline
\end{tabular}

All values are presented as means \pm SEM. $n=10$. Paired student twotailed $t$ test was used to compare between GLC and CDX. Significance was set at $P<0.05$

iAUC incremental area under the curve, $T_{\max }$ time to reach maximum concentration, EAA essential amino acids, $B C A A$ branched-chain amino acids, $C D X$ cluster dextrin, $G L C$ glucose, TTR tracer to tracee ratio, $S E M$ standard error of mean, $I U$ international unit

*Significant difference between groups $(P<0.05)$

was increased from baseline at all time points in CDX group $(P<0.05)$, and it was greater in CDX than GLC $(P<0.05)$ at $60 \mathrm{~min}$ (6.6- vs 16.7 -fold) and $180 \mathrm{~min}$ (5.6- vs 16.2 -fold). The phosphorylation of eEF2 ${ }^{\text {Thr56 }}$ (Fig. 5e) was decreased from baseline at $60 \mathrm{~min}(P<0.01)$. The phosphorylation of ERK1/2 ${ }^{\text {Thr202/Tyr204 }}$ (Fig. 5f) was increased from baseline at all time points $(P<0.05)$, and CDX was greater as compared to GLC at all time points (1.1- vs 1.7-fold, 1.2- vs 1.6-fold, 0.9 - vs 1.6 -fold for 30, 60, $180 \mathrm{~min}$, respectively, $P<0.05)$. The phosphorylation of AMPKo ${ }^{\text {Thr172 }}$ (Fig. 5g) was greater in CDX than GLC at 180 min (0.9- vs 1.3 -fold, $P<0.05)$.

\section{Discussion}

In the present study, we simultaneously assessed orally ingested protein-derived amino acid availability in the circulation using intrinsically labelled meat protein hydrolysate $\left(\mathrm{D}_{5}\right.$-phenylalanine) and myofibrillar protein synthesis of the vastus lateralis muscle after a whole-body resistance exercise in moderately trained younger males. Co-ingestion of CDX with meat protein hydrolysate did not enhance the total availability of protein-derived amino acids in the circulation as determined by the enrichment of serum $\mathrm{D}_{5}$-phenylalanine 
derived from intrinsically labelled meat-protein, serum phenylalanine, EAA, BCAA, and muscle BCAA concentrations compared with GLC. Interestingly, the activation of mTORC1 signaling was higher in CDX than GLC following a whole-body resistance exercise. However, the enhanced activation of mTORC1 signaling did not increase postprandial myofibrillar FSR in CDX as compared to GLC.

Amino acid availability in the circulation is a determinant of muscle protein synthesis [10,11]. It has been well established that protein/amino acids ingestion stimulates muscle protein synthesis following the recovery from resistance exercise [2, 12, 14, 34-36]. In the previous studies, carbohydrate co-ingestion with protein was hypothesized to augment insulin secretion and enhance muscle protein synthesis following an acute bout of resistance exercise [15-17]. However, we and others previously demonstrated that amino acid availability is decreased when protein is ingested with carbohydrate [15-17] or other macronutrients [18, 19]. The nature of rapid gastric emptying of CDX [27] could be used as an approach to attenuate lower amino acid availability when protein is consumed with GLC. To our knowledge, this is the first study to investigate whether CDX ingestion together with the intake of protein hydrolysate (here meat protein-derived) enhanced the availability of constituent amino acids in the circulation as compared to GLC ingestion. We made use of a previously produced intrinsically labelled meat protein hydrolysate [18] to directly measure exogenous protein-derived amino acid availability (with $\mathrm{D}_{5}$-phenylalanine as a tracer) in the present study.

For the main outcome $\mathrm{D}_{5}$-phenylalanine enrichment tracer, it appeared in serum from 20 min post-exercise and was maintained until 180 min post-exercise in both CDX and GLC groups (Fig. 3a) and iAUC (total availability) of the tracer did not differ between CDX and GLC (Table 3). Further, $\mathrm{T}_{\max }$ for the tracer was not affected by CDX as compared to GLC. The group means for EAA and BCAA at $t=-0: 30$ and $t=0$ (Fig. 3) appeared different and were likely to cause the main effect of group in the two-way ANOVA test. Therefore, we further explored if there were any postprandial differences by calculating iAUC from $t=0$, which revealed no difference for the postprandial rise in EAA and BCAA concentrations between CDX and GLC (Table 3). With these data in mind, the time $\times$ group interaction effect for $\mathrm{D}_{5}$-phenylalanine enrichment (Fig. 3a, $P=0.0072)$ is hard to explain. Visually, it seems though that the $\mathrm{D}_{5}$-phenylalanine enrichment peaks and starts to decrease within the 3-h postprandial period in CDX, whereas it remains high in GLC. However, this is speculative, and more investigations are needed to enlighten this further. Of interest is though, that the $\mathrm{T}_{\max }$ serum BCAA showed a statistical significance $(P=0.049)$ and $\mathrm{T}_{\max }$ serum EAA showed a trend towards a statistical significance $(P=0.051$, Table 3$)$ although this is not the case for $\mathrm{D}_{5}$-phenylalanine. However, a flux of different amino acids is regulated by different amino acid transport mechanisms [37], and hence, phenylalanine may not be a representative tracer for the clearance of all amino acids. Overall, we conclude that co-ingestion of CDX with meat protein hydrolysate did not markedly affect serum amino acid availability during the three hours of recovery from a whole-body resistance exercise.

In the present study, insulin was increased above baseline between 30 and 90 min post-exercise drink with no difference between CDX and GLC (Fig. 3d). Previously, studies have shown that CDX intake alone does not affect glucose concentrations as compared to glucose [38] or maltodextrin [39]. Although some amino acids are insulinotropic [40, 41] and a higher insulin secretion is observed when protein is consumed in combination with carbohydrate [15-17] compared to protein alone, the similar serum amino acid concentrations in CDX and GLC groups in this study reject the expectations for the insulin concentrations to be different. However, due to the lack of a "meat protein hydrolysate alone" group in the present study, we cannot conclude whether the co-ingestion of CDX or GLC increased insulin concentration above levels induced by the meat protein hydrolysate alone, although this must be anticipated. The roles of insulin on muscle protein turnover have long been debated. Systematic reviews have concluded that insulin does not have a stimulatory or inhibitory effect on muscle protein synthesis [23], but instead plays an important role in attenuating muscle protein breakdown independent of amino acid availability [42]. The absence of increased muscle BCAA concentrations at 30 and $60 \mathrm{~min}$ (where serum concentrations are elevating and peaking, respectively) reveals that the intramuscular disappearance rate of amino acids equals the influx. We did not follow the amino acid tracers further in the intramuscular metabolic pathways, but we suggest that muscle protein synthesis and energy metabolism are responsible for the utilization of excess amino acids. This is due to the concomitant intramuscular availability of glucose, which would meet the major requirement for energy production, dampening the anaplerotic processes. The drop at $180 \mathrm{~min}$ in the muscle BCAA concentrations (Fig. 3f) agrees with serum EAA (Fig. 3c), phenylalanine (Fig. 3b), BCAA (Fig. 3e), and insulin concentrations (Fig. 3d) as these substrates had all returned to basal levels. Hence, it is likely that participants were in the postabsorptive period around 180 min post-exercise drink, and that the muscle BCAA pool at that time point was drained by either a net outflux into the circulation or by a request from translation processes or both [43].

It is generally agreed that $20 \mathrm{~g}$ of high-quality protein intake is required following resistance exercise (e.g., leg press and knee extension) to maximally stimulate muscle protein synthesis in younger individuals [2, 4]. However, Macnaughton et al. [28] reported findings that may suggest 
a

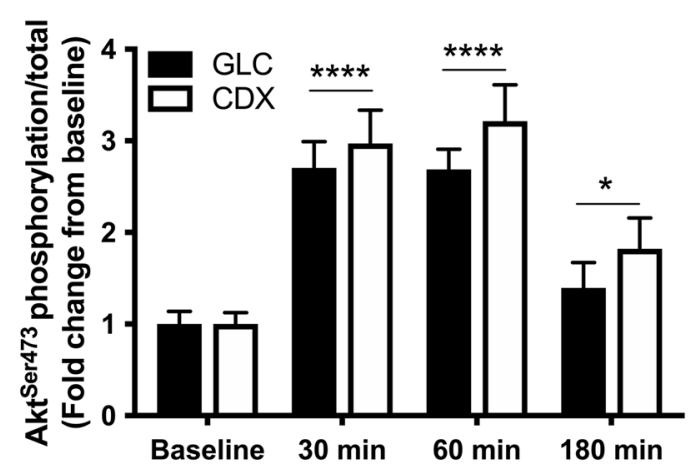

C

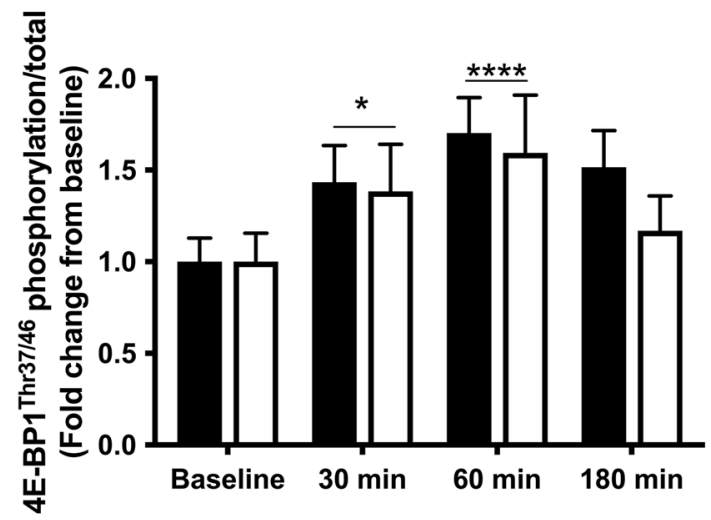

e

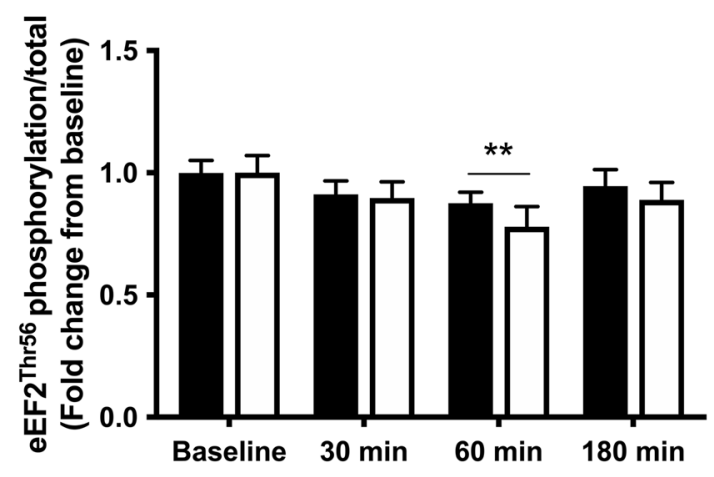

g

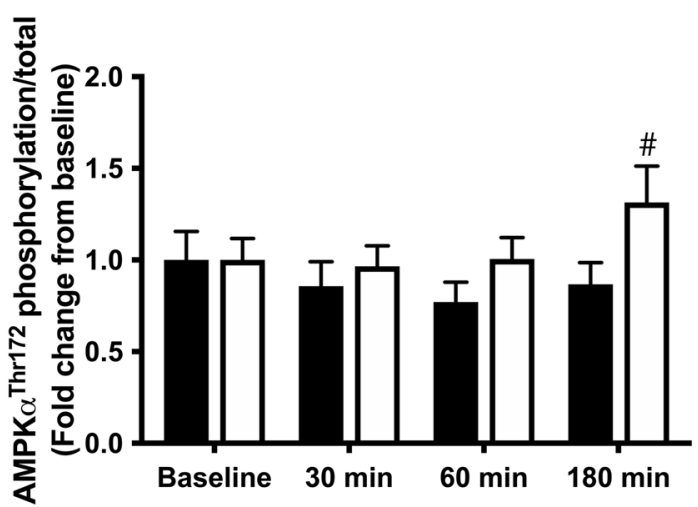

b

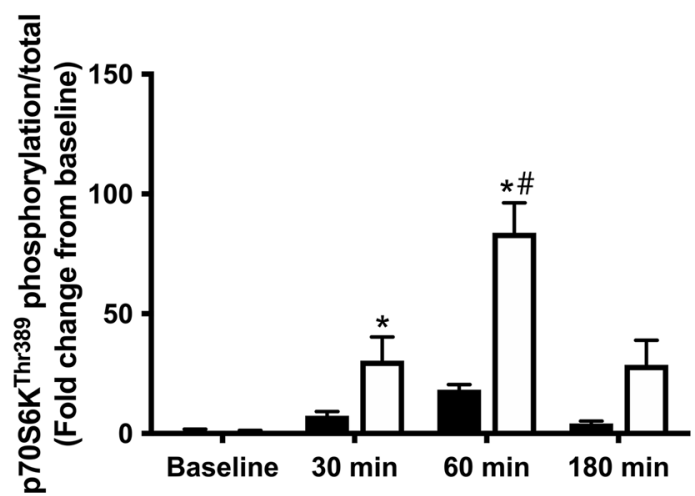

d

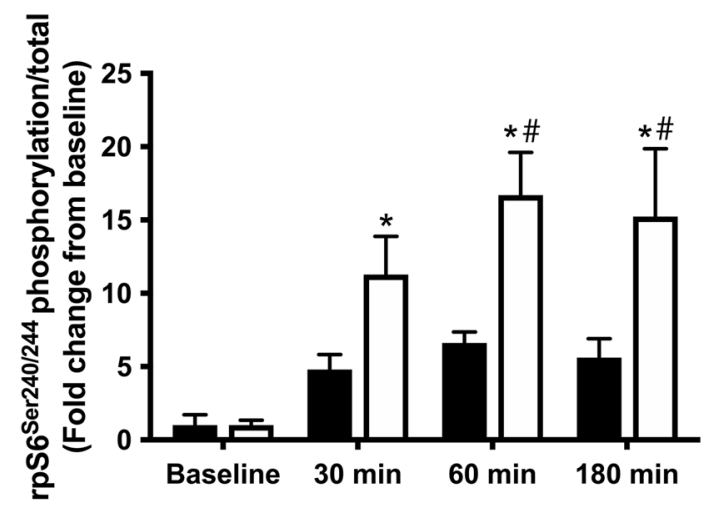

f

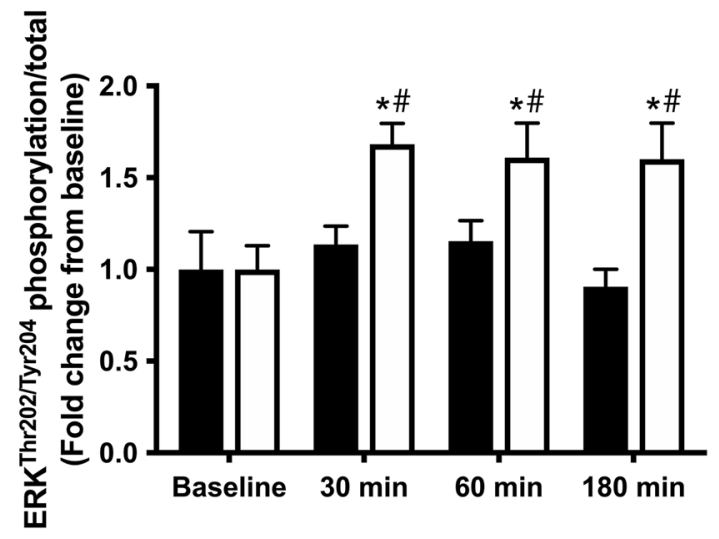


4 Fig. 5 The phosphorylation of $\mathrm{Akt}^{\mathrm{Ser} 473}$ (a), p70S6K $\mathrm{K}^{\mathrm{Thr} 389}$ (b), $4 \mathrm{E}-\mathrm{BP} 1^{\mathrm{Thr} 37 / 46}(\mathbf{c}), \mathrm{rpS6}^{\mathrm{Ser} 240 / 244}(\mathbf{d}), \mathrm{eEF}^{\mathrm{Thr} 56}(\mathbf{e}), \mathrm{ERK} 1 / 2^{\mathrm{Thr} 202 /}$ Tyr204 (f), AMPKo $\alpha^{\text {Thr172 }}$ (g) at 30, 60, 180 min after the ingestion of meat protein hydrolysate $\left(0.6 \mathrm{~g}\right.$ protein $\left.* \mathrm{FFM}^{-1}\right)$ with either GLC $(n=10)$ or CDX $(n=10)$. Data were analyzed with the use of a 2-factor [time $\times$ group (GLC compared with CDX)] ANOVA with Turkey's multiple comparisons test to locate individual differences. The data were expressed relative to baseline. Values are means \pm SEM. There was a main effect of time for $\mathrm{Akt}^{\mathrm{Ser} 473}, \mathrm{p} 70 \mathrm{~S} 6 \mathrm{~K}^{\mathrm{Thr} 389}, \mathrm{rpS6}^{\mathrm{Ser} 240 / 244}$, 4E-BP1 $1^{\text {Thr37/46, }}, \mathrm{eEF}^{\mathrm{Thr} 56}$, ERK1/2 ${ }^{\mathrm{Thr} 202 / \mathrm{Tyr} 204}$, and AMPKo ${ }^{\mathrm{Thr} 172}$ $(P<0.05)$. There was a main effect of group (GLC compared with $\mathrm{CDX}$ ) for $\mathrm{Akt}^{\mathrm{Ser} 473} \mathrm{p} 70 \mathrm{~S} 6 \mathrm{~K}^{\mathrm{Thr} 389}, \mathrm{rpS6}^{\mathrm{Ser} 240 / 244}$, ERK1/2 ${ }^{\mathrm{Thr} 202 / \mathrm{Ty} 204}$ $(P<0.05)$. There was a time $\times$ group interaction effect for

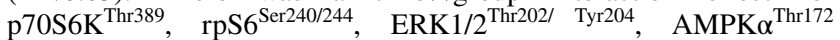
$(P<0.05)$. Significance was set at $P<0.05$. *, **, **** denotes significant difference from baseline in respective group $(P<0.05$, $P<0.01, P<0.0001)$. " indicates significant difference between CDX and GLC at the same time point $(P<0.05)$. GLC glucose, CDX cluster dextrin

the amount of protein required to stimulate muscle protein synthesis may depend on the amount of muscle recruited during resistance exercise. This is because the demand for exogenous amino acids might be increased when more muscles are used during resistance exercise (whole-body vs unilateral leg) although the amount of lean body mass (LBM) itself does not affect muscle protein synthesis [28]. Macnaughton et al. [28] provided either $0.34 \mathrm{~g}$ or $0.68 \mathrm{~g}$ protein * $\mathrm{LBM}^{-1}$ whey protein in the lower LBM group $(59 \mathrm{~kg} \mathrm{LBM}$ on average), and either $0.26 \mathrm{~g}$ protein or $0.52 \mathrm{~g}$ protein * $\mathrm{LBM}^{-1}$ in the higher LBM group (77 kg LBM on average). In the present study, participants performed a whole-body resistance exercise followed by meat protein hydrolysate $\left(0.6 \mathrm{~g}^{*} \mathrm{FFM}^{-1}\right)$ intake, which ended up as a mean of $36.3 \mathrm{~g}$ of meat protein hydrolysate (range 32.0 to $41.6 \mathrm{~g}$ ) to our participants, which should provide a stimulus to maximally stimulate myofibrillar FSR following a whole-body resistance exercise. However, as we did not measure the baseline myofibrillar FSR we cannot say whether the myofibrillar FSR was enhanced by an acute bout of whole-body resistance exercise.

$\mathrm{Akt} / \mathrm{mTORC} 1$ signaling pathway is crucial for muscle protein synthesis and skeletal muscle hypertrophy [7, 44, 45]. Previous studies showed that protein/amino acid feeding [7, 46-48], resistance exercise [35, 49-52], or a combination of both $[12,14,35,36,53]$ activate Akt/mTORC1 signaling in younger individuals. In line, our whole-body resistance exercise protocol with postexercise meat protein hydrolysate ingestion increased the phosphorylation of $\mathrm{Akt}^{\mathrm{Ser} 473}, \mathrm{p} 70 \mathrm{~S} 6 \mathrm{~K}^{\mathrm{Thr} 389}, \mathrm{rpS6}^{\mathrm{Ser} 240 / 244}$, 4E-BP1 $1^{\text {Thr37/46 }}$, and ERK1/2 ${ }^{\text {Thr202/Tyr204 }}$ and decreased the phosphorylation of eEF2 $2^{\text {Thr56 }}$ over the course of $180 \mathrm{~min}$ post-exercise period (a main effect for time, $P<0.05$ ). Interestingly, the phosphorylation of $\mathrm{p} 70 \mathrm{~S} 6 \mathrm{~K}^{\mathrm{Thr} 389}$, $\mathrm{rpS}^{\mathrm{Ser} 240 / 244}$, and ERK1/2 ${ }^{\mathrm{Thr} 202 / \mathrm{Tyr} 204}$ was greater in CDX compared to GLC during the recovery from a whole-body resistance exercise (a time $\times$ group interaction effect, $P<0.05)$, indicating an enhanced translation initiation and elongation in CDX. However, the enhanced mTORC1 signaling did not result in an increased postprandial myofibrillar FSR in CDX (Fig. 4), which is in line with previous studies that demonstrated that co-ingestion of carbohydrate does not further increase FSR compared to protein intake alone [15-17]. The absence of an enhanced postprandial myofibrillar FSR in CDX despite the increased mTORC1 signaling could be explained by no changes of amino acids availability in the circulation as well as muscle BCAA concentrations (Fig. 3). Previous studies have shown that metabolic flux in vivo cannot be predicted by intracellular signaling [54] or mRNA expression level [55]. In support, dissociation between Akt/mTORC 1 signaling and muscle protein synthesis in response to amino acids and insulin was previously reported by Greenhaff et al. [56].

The present randomized controlled crossover trial is a robust study design with high statistical power. However, the absence of a meat protein hydrolysate group alone makes it impossible to reveal any effects of CDX or GLC per se, which could have been interesting now that the hypothesized beneficial effects of CDX could not be verified.

\section{Conclusions}

In moderately trained younger males, co-ingestion of CDX with meat protein hydrolysate does not enhance the availability of protein-derived amino acids and myofibrillar FSR as compared to GLC with meat protein hydrolysate during the recovery from a whole-body resistance exercise despite an increased intramuscular signaling. 

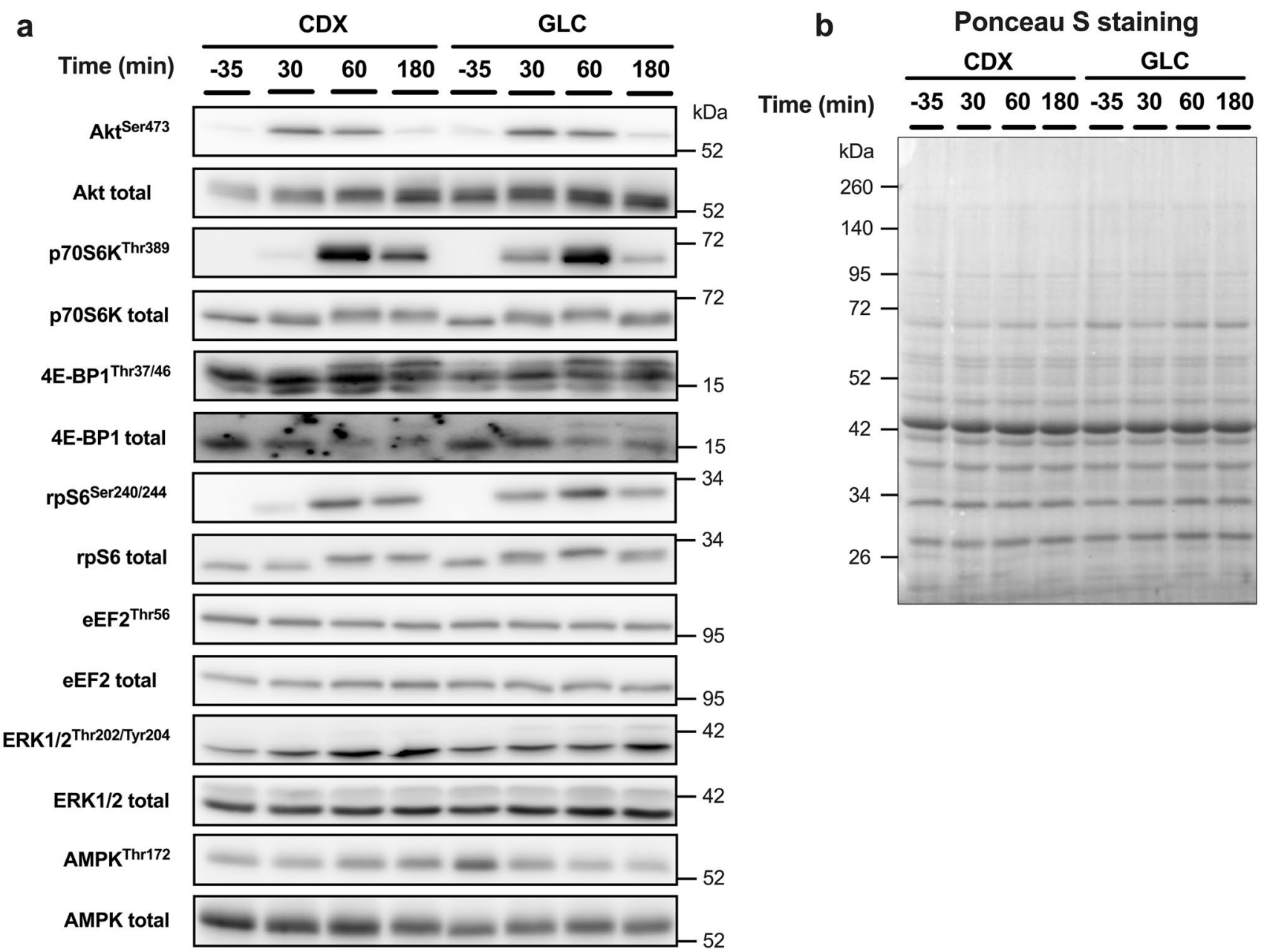

Fig. 6 Representative western blot images for intracellular signaling (a) and Ponceau-S (b). CDX cluster dextrin, $G L C$ glucose

Acknowledgements The authors would like to thank the research participants for their time and effort.

Author contributions $\mathrm{YN}$ : formal analysis, data curation, visualization, writing — original draft, writing-review and editing. MJ: methodology, validation, formal analysis, investigation, writing — original draft, writing — review and editing. JB: methodology, investigation, writingreview and editing. TTT: methodology, investigation, writing-review and editing. TA: methodology, formal analysis, writing-review and editing. GVH: methodology, formal analysis, writing-review and editing. SF: conceptualization, methodology, validation, data curation, visualization, supervision, funding acquisition, writing — original draft, writing-review and editing. LH: conceptualization, methodology, validation, data curation, visualization, supervision, project administration, funding acquisition. Writing — original draft, writing — review and editing.

Funding Glico Nutrition Co., Ltd., Osaka, Japan.

Availability of data and material The datasets generated during and analyzed during the current study are available from the corresponding author on reasonable request.
Code availability Not applicable.

\section{Declarations}

Conflict of interest The authors declare no conflicts of interest.

Ethical approval This study was approved by the Ethics Committee of the Capital Region (H-17017363) and adhered with the Helsinki II declaration.

Consent to participate Before inclusion, each participant was informed of the purpose of the study, experimental procedures, and potential risks prior to obtaining written informed consent.

Consent for publication All authors read the final version of the manuscript and approved for publication.

Open Access This article is licensed under a Creative Commons Attribution 4.0 International License, which permits use, sharing, adaptation, distribution and reproduction in any medium or format, as long as you give appropriate credit to the original author(s) and the source, provide a link to the Creative Commons licence, and indicate if changes were made. The images or other third party material in this article are 
included in the article's Creative Commons licence, unless indicated otherwise in a credit line to the material. If material is not included in the article's Creative Commons licence and your intended use is not permitted by statutory regulation or exceeds the permitted use, you will need to obtain permission directly from the copyright holder. To view a copy of this licence, visit http://creativecommons.org/licenses/by/4.0/.

\section{References}

1. Morton RW, Murphy KT, McKellar SR, Schoenfeld BJ, Henselmans M, Helms E, Aragon AA, Devries MC, Banfield L, Krieger JW, Phillips SM (2018) A systematic review, metaanalysis and meta-regression of the effect of protein supplementation on resistance training-induced gains in muscle mass and strength in healthy adults. Br J Sports Med 52(6):376-384. https://doi.org/10.1136/bjsports-2017-097608

2. Witard OC, Jackman SR, Breen L, Smith K, Selby A, Tipton KD (2013) Myofibrillar muscle protein synthesis rates subsequent to a meal in response to increasing doses of whey protein at rest and after resistance exercise-. Am J Clin Nutr 99(1):86-95

3. Wolfe RR (2006) Skeletal muscle protein metabolism and resistance exercise. J Nutr 136(2):525S-528S. https://doi.org/ $10.1093 / \mathrm{jn} / 136.2 .525 \mathrm{~S}$

4. Moore DR, Robinson MJ, Fry JL, Tang JE, Glover EI, Wilkinson SB, Prior T, Tarnopolsky MA, Phillips SM (2009) Ingested protein dose response of muscle and albumin protein synthesis after resistance exercise in young men. Am J Clin Nutr 89(1):161-168. https://doi.org/10.3945/ajen.2008.26401

5. Tipton KD, Ferrando AA, Phillips SM, Doyle D Jr, Wolfe RR (1999) Postexercise net protein synthesis in human muscle from orally administered amino acids. Am J Physiol 276(4):E628634. https://doi.org/10.1152/ajpendo.1999.276.4.E628

6. Volpi E, Kobayashi H, Sheffield-Moore M, Mittendorfer B, Wolfe RR (2003) Essential amino acids are primarily responsible for the amino acid stimulation of muscle protein anabolism in healthy elderly adults. Am J Clin Nutr 78(2):250-258. https:// doi.org/10.1093/ajen/78.2.250

7. Fujita S, Dreyer HC, Drummond MJ, Glynn EL, Cadenas JG, Yoshizawa F, Volpi E, Rasmussen BB (2007) Nutrient signalling in the regulation of human muscle protein synthesis. J Physiol 582(Pt 2):813-823. https://doi.org/10.1113/jphysiol.2007.134593

8. Anthony JC, Anthony TG, Kimball SR, Jefferson LS (2001) Signaling pathways involved in translational control of protein synthesis in skeletal muscle by leucine. J Nutr 131(3):856S-860S. https:// doi.org/10.1093/jn/131.3.856S

9. Atherton PJ, Smith K, Etheridge T, Rankin D, Rennie MJ (2010) Distinct anabolic signalling responses to amino acids in $\mathrm{C} 2 \mathrm{C} 12$ skeletal muscle cells. Amino Acids 38(5):1533-1539. https://doi. org/10.1007/s00726-009-0377-x

10. Pennings B, Boirie Y, Senden JM, Gijsen AP, Kuipers H, van Loon LJ (2011) Whey protein stimulates postprandial muscle protein accretion more effectively than do casein and casein hydrolysate in older men. Am J Clin Nutr 93(5):997-1005. https://doi. org/10.3945/ajen.110.008102

11. Bohe J, Low A, Wolfe RR, Rennie MJ (2003) Human muscle protein synthesis is modulated by extracellular, not intramuscular amino acid availability: a dose-response study. J Physiol 552(Pt 1):315-324. https://doi.org/10.1113/jphysiol.2003.050674

12. West DW, Burd NA, Coffey VG, Baker SK, Burke LM, Hawley JA, Moore DR, Stellingwerff T, Phillips SM (2011) Rapid aminoacidemia enhances myofibrillar protein synthesis and anabolic intramuscular signaling responses after resistance exercise. Am J Clin Nutr 94(3):795-803. https://doi.org/10.3945/ajcn.111. 013722
13. Tang JE, Moore DR, Kujbida GW, Tarnopolsky MA, Phillips SM (2009) Ingestion of whey hydrolysate, casein, or soy protein isolate: effects on mixed muscle protein synthesis at rest and following resistance exercise in young men (Bethesda, Md: 1985). J Appl Physiol 107(3):987-992. https://doi.org/10.1152/japplphysi ol.00076.2009

14. Reitelseder S, Agergaard J, Doessing S, Helmark IC, Lund P, Kristensen NB, Frystyk J, Flyvbjerg A, Schjerling P, van Hall G, Kjaer M, Holm L (2011) Whey and casein labeled with L-[113C]leucine and muscle protein synthesis: effect of resistance exercise and protein ingestion. Am J Physiol Endocrinol Metab 300(1):E231-242. https://doi.org/10.1152/ajpendo.00513.2010

15. Staples AW, Burd NA, West DW, Currie KD, Atherton PJ, Moore DR, Rennie MJ, Macdonald MJ, Baker SK, Phillips SM (2011) Carbohydrate does not augment exercise-induced protein accretion versus protein alone. Med Sci Sports Exerc 43(7):1154-1161

16. Gorissen SH, Burd NA, Hamer HM, Gijsen AP, Groen BB, van Loon LJ (2014) Carbohydrate coingestion delays dietary protein digestion and absorption but does not modulate postprandial muscle protein accretion. J Clin Endocrinol Metab 99(6):2250-2258. https://doi.org/10.1210/jc.2013-3970

17. Koopman R, Beelen M, Stellingwerff T, Pennings B, Saris WH, Kies AK, Kuipers H, van Loon LJ (2007) Coingestion of carbohydrate with protein does not further augment postexercise muscle protein synthesis. Am J Physiol Endocrinol Metab 293(3):E833842. https://doi.org/10.1152/ajpendo.00135.2007

18. Reitelseder S, Tranberg B, Agergaard J, Dideriksen K, Hojfeldt G, Merry ME, Storm AC, Poulsen KR, Hansen ET, van Hall G, Lund P, Holm L (2020) Phenylalanine stable isotope tracer labeling of cow milk and meat and human experimental applications to study dietary protein-derived amino acid availability. Clin Nutr (Edinburgh, Scotland) 39(12):3652-3662. https://doi.org/10.1016/j. clnu.2020.03.017

19. Yoshii N, Sato K, Ogasawara R, Nishimura Y, Shinohara Y, Fujita $\mathrm{S}$ (2018) Effect of mixed meal and leucine intake on plasma amino acid concentrations in young men. Nutrients 10(10):1543. https:// doi.org/10.3390/nu10101543

20. Deutz NE, Ten Have GA, Soeters PB, Moughan PJ (1995) Increased intestinal amino-acid retention from the addition of carbohydrates to a meal. Clin Nutr (Edinburgh, Scotland) 14(6):354 364. https://doi.org/10.1016/s0261-5614(95)80053-0

21. Kim IY, Deutz NEP, Wolfe RR (2018) Update on maximal anabolic response to dietary protein. Clin Nutr (Edinburgh, Scotland) 37(2):411-418. https://doi.org/10.1016/j.clnu.2017.05.029

22. Nishimura Y, Højfeldt G, Breen L, Tetens I, Holm L (2021) Dietary protein requirements and recommendations for healthy older adults-a critical narrative review of the scientific evidence. Nutr Res Rev. https://doi.org/10.1017/S0954422421000329

23. Trommelen J, Groen BB, Hamer HM, de Groot LC, van Loon LJ (2015) Mechanisms in endocrinology: exogenous insulin does not increase muscle protein synthesis rate when administered systemically: a systematic review. Eur J Endocrinol 173(1):R25-34. https://doi.org/10.1530/EJE-14-0902

24. Takata H, Takaha T, Okada S, Takagi M, Imanaka T (1996) Cyclization reaction catalyzed by branching enzyme. J Bacteriol 178(6):1600-1606. https://doi.org/10.1128/jb.178.6.1600-1606. 1996

25. Takii H, Ishihara K, Kometani T, Okada S, Fushiki T (1999) Enhancement of swimming endurance in mice by highly branched cyclic dextrin. Biosci Biotechnol Biochem 63(12):2045-2052. https://doi.org/10.1271/bbb.63.2045

26. Takata H, Takaha T, Nakamura H, Fujii K, Okada S, Takagi M, Imanaka T (1997) Production and some properties of a dextrin with a narrow size distribution by the cyclization reaction of branching enzyme. J Ferment Bioeng 84(2):119-123 
27. Takii H, Takii Nagao Y, Kometani T, Nishimura T, Nakae T, Kuriki T, Fushiki T (2005) Fluids containing a highly branched cyclic dextrin influence the gastric emptying rate. Int J Sports Med 26(4):314-319. https://doi.org/10.1055/s-2004-820999

28. Macnaughton LS, Wardle SL, Witard OC, McGlory C, Hamilton DL, Jeromson S, Lawrence CE, Wallis GA, Tipton KD (2016) The response of muscle protein synthesis following whole-body resistance exercise is greater following $40 \mathrm{~g}$ than $20 \mathrm{~g}$ of ingested whey protein. Physiol Rep. https://doi.org/10.14814/phy2.12893

29. Bergstrom J (1975) Percutaneous needle biopsy of skeletal muscle in physiological and clinical research. Scand J Clin Lab Invest 35(7):609-616

30. Bornø A, van Hall G (2014) Quantitative amino acid profiling and stable isotopically labeled amino acid tracer enrichment used for in vivo human systemic and tissue kinetics measurements. J Chromatogr B 951:69-77

31. Borno A, Hulston CJ, van Hall G (2014) Determination of human muscle protein fractional synthesis rate: an evaluation of different mass spectrometry techniques and considerations for tracer choice. J Mass Spectrom 49(8):674-680. https://doi.org/10.1002/ jms.3387

32. Kido K, Ato S, Yokokawa T, Sato K, Fujita S (2018) Resistance training recovers attenuated APPL1 expression and improves insulin-induced Akt signal activation in skeletal muscle of type 2 diabetic rats. Am J Physiol Endocrinol Metab 314(6):E564-E571. https://doi.org/10.1152/ajpendo.00362.2017

33. Wolfe RR, Chinkes DL (2004) Isotope tracers in metabolic research: principles and practice of kinetic analysis. John Wiley $\&$ Sons

34. Yang Y, Breen L, Burd NA, Hector AJ, Churchward-Venne TA, Josse AR, Tarnopolsky MA, Phillips SM (2012) Resistance exercise enhances myofibrillar protein synthesis with graded intakes of whey protein in older men. Br J Nutr 108(10):1780-1788. https:// doi.org/10.1017/S0007114511007422

35. Dreyer HC, Drummond MJ, Pennings B, Fujita S, Glynn EL, Chinkes DL, Dhanani S, Volpi E, Rasmussen BB (2008) Leucine-enriched essential amino acid and carbohydrate ingestion following resistance exercise enhances mTOR signaling and protein synthesis in human muscle. Am J Physiol Endocrinol Metab 294(2):E392-400. https://doi.org/10.1152/ajpendo.00582.2007

36. Drummond MJ, Dreyer HC, Pennings B, Fry CS, Dhanani S, Dillon EL, Sheffield-Moore M, Volpi E, Rasmussen BB (2008) Skeletal muscle protein anabolic response to resistance exercise and essential amino acids is delayed with aging. J Appl Physiol 104(5):1452-1461

37. Hundal HS, Taylor PM (2009) Amino acid transceptors: gate keepers of nutrient exchange and regulators of nutrient signaling. Am J Physiol-Endocrinol Metab 296(4):E603-E613

38. Takii H, Kometani T, Nishimura T, Kuriki T, Fushiki T (2004) A sports drink based on highly branched cyclic dextrin generates few gastrointestinal disorders in untrained men during bicycle exercise. Food Sci Technol Res 10(4):428-431. https://doi.org/ 10.3136/fstr.10.428

39. Furuyashiki T, Tanimoto H, Yokoyama Y, Kitaura Y, Kuriki T, Shimomura Y (2014) Effects of ingesting highly branched cyclic dextrin during endurance exercise on rating of perceived exertion and blood components associated with energy metabolism. Biosci Biotechnol Biochem 78(12):2117-2119

40. Newsholme P, Brennan L, Bender K (2006) Amino acid metabolism, $\beta$-cell function, and diabetes. Diabetes 55(Supplement 2):S39-S47

41. Lundholm K, Bennegård K, Zachrisson H, Lundgren F, Eden E, Möller-Loswick A (1987) Transport kinetics of amino acids across the resting human leg. J Clin Investig 80(3):763-771
42. Abdulla H, Smith K, Atherton PJ, Idris I (2016) Role of insulin in the regulation of human skeletal muscle protein synthesis and breakdown: a systematic review and meta-analysis. Diabetologia 59(1):44-55. https://doi.org/10.1007/s00125-015-3751-0

43. Wolfe RR (2017) Branched-chain amino acids and muscle protein synthesis in humans: myth or reality? J Int Soc Sports Nutr 14:30. https://doi.org/10.1186/s12970-017-0184-9

44. Bodine SC, Stitt TN, Gonzalez M, Kline WO, Stover GL, Bauerlein R, Zlotchenko E, Scrimgeour A, Lawrence JC, Glass DJ, Yancopoulos GD (2001) Akt/mTOR pathway is a crucial regulator of skeletal muscle hypertrophy and can prevent muscle atrophy in vivo. Nat Cell Biol 3(11):1014-1019. https://doi.org/10.1038/ ncb1101-1014

45. Baar K, Esser K (1999) Phosphorylation of p70(S6k) correlates with increased skeletal muscle mass following resistance exercise. Am J Physiol 276(1):C120-127. https://doi.org/10.1152/ajpcell. 1999.276.1.C120

46. Cuthbertson D, Smith K, Babraj J, Leese G, Waddell T, Atherton P, Wackerhage H, Taylor PM, Rennie MJ (2005) Anabolic signaling deficits underlie amino acid resistance of wasting, aging muscle. FASEB J: Off Publ Fed Am Soc Exp Biol 19(3):422-424. https://doi.org/10.1096/fj.04-2640fje

47. Atherton PJ, Etheridge T, Watt PW, Wilkinson D, Selby A, Rankin D, Smith K, Rennie MJ (2010) Muscle full effect after oral protein: time-dependent concordance and discordance between human muscle protein synthesis and mTORC1 signaling. Am J Clin Nutr 92(5):1080-1088. https://doi.org/10.3945/ajcn.2010. 29819

48. Dickinson JM, Fry CS, Drummond MJ, Gundermann DM, Walker DK, Glynn EL, Timmerman KL, Dhanani S, Volpi E, Rasmussen BB (2011) Mammalian target of rapamycin complex 1 activation is required for the stimulation of human skeletal muscle protein synthesis by essential amino acids. J Nutr 141(5):856-862. https:// doi.org/10.3945/jn.111.139485

49. Cuthbertson DJ, Babraj J, Smith K, Wilkes E, Fedele MJ, Esser K, Rennie M (2006) Anabolic signaling and protein synthesis in human skeletal muscle after dynamic shortening or lengthening exercise. Am J Physiol Endocrinol Metab 290(4):E731-738. https://doi.org/10.1152/ajpendo.00415.2005

50. Dreyer HC, Fujita S, Cadenas JG, Chinkes DL, Volpi E, Rasmussen BB (2006) Resistance exercise increases AMPK activity and reduces $4 \mathrm{E}-\mathrm{BP} 1$ phosphorylation and protein synthesis in human skeletal muscle. J Physiol 576(Pt 2):613-624. https://doi.org/10. 1113/jphysiol.2006.113175

51. Kumar V, Selby A, Rankin D, Patel R, Atherton P, Hildebrandt W, Williams J, Smith K, Seynnes O, Hiscock N, Rennie MJ (2009) Age-related differences in the dose-response relationship of muscle protein synthesis to resistance exercise in young and old men. J Physiol 587(1):211-217. https://doi.org/10.1113/jphysiol.2008. 164483

52. Fry CS, Drummond MJ, Glynn EL, Dickinson JM, Gundermann DM, Timmerman KL, Walker DK, Dhanani S, Volpi E, Rasmussen BB (2011) Aging impairs contraction-induced human skeletal muscle mTORC1 signaling and protein synthesis. Skeletal muscle 1(1):11. https://doi.org/10.1186/2044-5040-1-11

53. Koopman R, Pennings B, Zorenc AH, Van Loon LJ (2007) Protein ingestion further augments S6K1 phosphorylation in skeletal muscle following resistance type exercise in males. J Nutr 137(8):1880-1886

54. Bukhari SS, Phillips BE, Wilkinson DJ, Limb MC, Rankin D, Mitchell WK, Kobayashi H, Greenhaff PL, Smith K, Atherton PJ (2015) Intake of low-dose leucine-rich essential amino acids stimulates muscle anabolism equivalently to bolus whey protein in older women at rest and after exercise. Am J Physiol Endocrinol 
Metab 308(12):E1056-1065. https://doi.org/10.1152/ajpendo. 00481.2014

55. Neinast MD, Jang C, Hui S, Murashige DS, Chu Q, Morscher RJ, Li X, Zhan L, White E, Anthony TG, Rabinowitz JD, Arany Z (2019) Quantitative analysis of the whole-body metabolic fate of branched-chain amino acids. Cell Metab 29(2):417-429.e414. https://doi.org/10.1016/j.cmet.2018.10.013
56. Greenhaff PL, Karagounis LG, Peirce N, Simpson EJ, Hazell M, Layfield R, Wackerhage H, Smith K, Atherton P, Selby A, Rennie MJ (2008) Disassociation between the effects of amino acids and insulin on signaling, ubiquitin ligases, and protein turnover in human muscle. Am J Physiol Endocrinol Metab 295(3):E595-604. https://doi.org/10.1152/ajpendo.90411.2008 